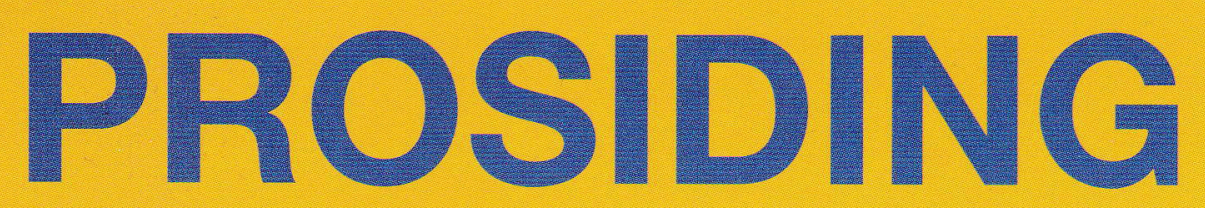

Bidang Pendidikan Agama dan Keagamaan

Volume 3 No. 1 Tahun 2016 - ISSN : 2354-5747

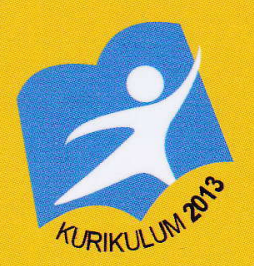

\title{
EVALUASI KURIKULUM 2013
}

\section{MATA PELAJARAN}

PENDIDIKAN AGAMA ISLAM

PADA SMA DI JAWA TENGAH DAN

D.I. YOGYAKARTA
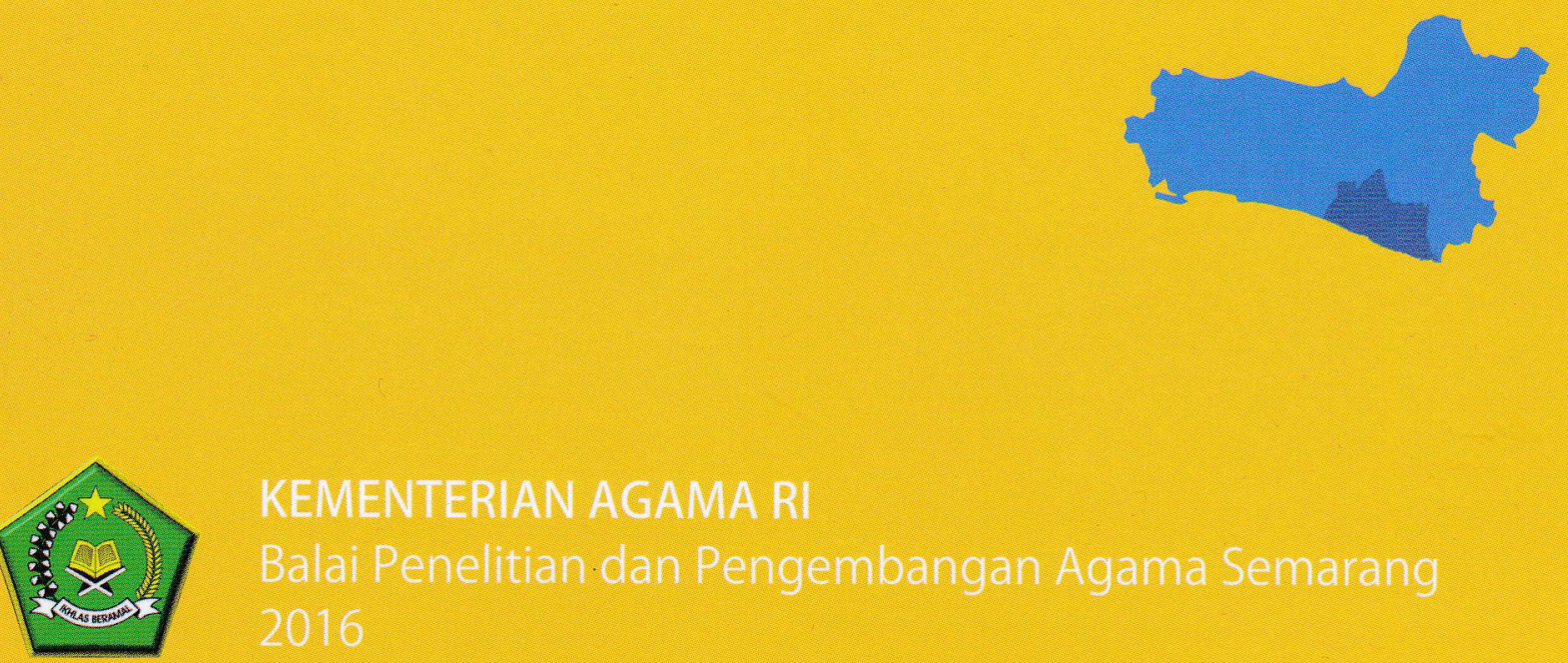

KEMENTERIAN AGAMA RI

Balai Penelitian dan Pengembangan Agama Semarang 2016 


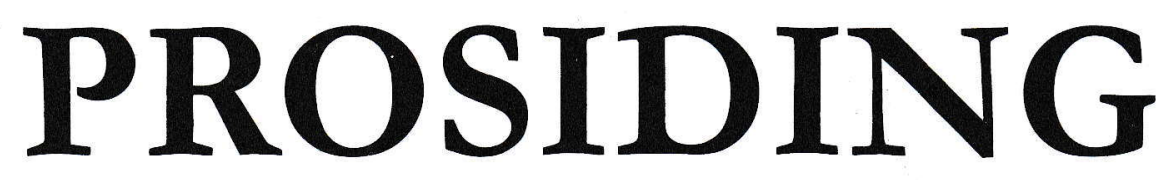

Bidang Pendidikan Agama dan Keagamaan

Volume 3 No. 1 Tahun 2016 ISSN: 2354-5747

\section{EVALUASI KURIKULUM 2013 \\ MATA PELAJARAN PENDIDIKAN AGAMA ISLAM PADA SMA DI JAWA TENGAH DAN D.I. YOGYAKARTA}

Kementerian Agama

Balai Penelitian dan Pengembangan Agama Semarang 2016 


\section{Susunan Redaksi}

\section{Penanggung Jawab}

Prof. (R) DR. H. Koeswinarno, M. Hum

(Kepala Balai Litbang Agama Semarang)

\section{Dewan Penyunting}

Nugroho Eko Atmanto (Ketua)

Yustiani

Mukhtaruddin

Umi Muzayanah

Wahab

Mulyani Mudis Taruna

Sulaiman

Joko Tri Haryanto

Umi Masfiah

Ahmad Sidik

Setyo Boedi Oetomo

Zakiyah

\section{Layouter}

Musafak

Muhammad Purbaya 


\section{KATA PENGANTAR \\ KETUA PANITIA}

Pertama-tama marilah kita panjatkan puji syukur ke hadirat Allah SWT. yang senantiasa melimpahkan rahmat dan karunia-Nya kepada kita semua, sehingga kami mampu menyelesaikan laporan kegiatan seminar hasil penelitian Pelaksanaan Kurikulum 2013 Mata Pelajaran Pendidikan Agama Islam di Jawa Tengah.

Kegiatan ini diikuti oleh praktisi guru Pendidikan Agama Islam, pengawas, perguruan tinggi, Balai Diklat Keagamaan, Kementerian Agama, serta peneliti Balai Litbang Agama Semarang. Kegiatan tersebut bertujuan untuk mensosialisasikan hasil penelitian yang telah dilakukan oleh Tim Peneliti Bidang Pendidikan Agama dan Keagamaan Balai Litbang Agama Semarang di beberapa Kabupaten di Jawa Tengah dan DIY. Melalui seminarini diharapkan seluruh peserta terlibat aktif dalam memberikan kritik, saran, dan masukan serta shraing pengalaman dalam penerapan Kurikulum 2013.

Kami selaku panitia melaporkan, kegiatan ini dilaksanakan pada tanggal 7 bulan Mei 2015 bertempat di Balai Diklat Keagamaan Semarang. Laporan ini meliputi latar belakang kegiatan, tujuan kegiatan hingga dokumentasi dan menghasilkan beberapa rekomendasi penelitian.

Kami selaku panitia mengucapkan terima kasih kepada Kepala Balai Litbang Agama Semarang yang telah memberikan kepercayaan kepada kami untuk melaksanakan kegiatan dan membuat laporan. Semoga hal tersebut dapat memberikan manfaat bagi kita semua dan sebagai bentuk tanggungjawab kepada pemerintah dalam hal ini (Kementerian Agama RI).

Demikian sambutan panitia penyelenggara seminar kami sampaikan, atas segala kekurangan kami menyampaikan permohonan maaf yang sebesar-besarnya. Kritik dan saran yang sifatnya membangun selalu kami harapkan sebagai bahan perbaikan di masa mendatang.

Ketua Panitia 


\section{KATA SAMBUTAN}

\section{KEPALA BALAI LITBANG AGAMA SEMARANG}

Puji dan syukur kami panjatkan kehadirat Tuhan Yang Maha Esa atas limpahan rahmat dan karunia-Nya, sehingga kami dapat merealisasikan "Penerbitan Buku Keagamaan" tahun 2016. Penerbitan buku ini merupakan hasil penelitian Balai Penelitian dan Pengembangan Agama Semarang, yang meliputi tiga bidang, yakni Kehidupan Keagamaan, Pendidikan Agama dan Keagamaan, Lektur dan Khazanah Keagamaan.

Buku hasil penelitian yang diterbitkan pada tahun 2016 sebanyak 5 naskah. Naskah-naskah tersebut diterbitkan dalam bentuk bunga rampai sebanyak 2 judul dan bentuk prosiding sebanyak 3 judul. Berikut ini adalah judul-judul artikel pada penerbitan prosiding Pendidikan Agama dan Keagamaan sebagai berikut:

1. Pelaksanaan Kurikulum 2013 Pada Jenjang Pendidikan Menengah (Studi Evaluasi terhadap Proses Pembelajaran Mata Pelajaran Pendidikan Agama Islam (PAI) pada SMAN 1 Godean Sleman)

2. Evaluasi Pelaksanaan Kurikulum 2013 Mata Pelajaran PAI dan Budi Pekerti di SMAN 1 Bantul.

3. Evaluasi Pelaksanaan Kurikulum 2013 pada Mata Pelajaran PAI dan Budi Pekerti pada SMAN 1 Wonosari Kabupaten Gunungkidul.

4. Evaluasi Pelaksanaan Kurikulum 2013 Mata Pelajaran Pendidikan Agama Islam di SMAN 1 Kudus.

5. Evaluasi pelaksanaan Kurikulum 2013 (Studi Pada SMA Negeri Di Kabupaten Banyumas)

6. Evaluasi Pelaksanaan Kurikulum 2013 Mata Pelajaran Pendidikan Agama Islam (Studi pada SMA N I Magelang)

Proses penerbitan ini telah melalui proses evaluasi dan editing yang ketat dari Tim Penjamin Mutu Internal Peneliti (TPMIP) Balai Litbang Agama Semarang. Tim ini dibentuk untuk kepentingan peningkatan kualitas hasil penelitian dan penerbitan. Salah satu hasil kerja TPMIP adalah terbitnya ke-5 buku dan prosiding yang merupakan hasil karya para peneliti Balai Litbang Agama Semarang. Dengan selesainya penerbitan buku-buku keagamaan ini, kami mengucapkan terima kasih kepada:

1. Kepala Badan Litbang dan Diklat Kementerian Agama RI yang telah memberikan kepercayaan, dan arahannya demi terwujudnya penerbitan buku ini

2. Para pakar yang telah memberikan prolog dan kontribusi pengetahuan atas diterbitkannya buku ini

3. Para Tim Penjamin Mutu Internal Peneliti (TPMIP) Balai Litbang Agama Semarang yang telah tekun untuk menyelaraskan laporan hasil penelitian sehingga menjadi sebuah naskah buku yang telah diterbitkan.

4. Para peneliti yang telah merelakan karya hasil penelitiannya untuk diterbitkan sebagai buku

5. Semua pihak yang telah memberikan kontribusi bagi terlaksananya program penerbitan buku-buku keagamaan oleh Balai Litbang Agama Semarang 


\section{KATA PENGANTAR EDITOR}

Kurikulum 2013 yang merupakan kelanjutan dari Kurikulum Tingkat Satuan Pelajaran telah digulirkan oleh Menteri Pendidikan dan Kebudayaan pada bulan Juli 2013 dan diterapkan di beberapa sekolah secara terbatas sebagai proyek percontohan (pilot project). Semua pelajaran tidak terkecuali mata pelajaran Pendidikan Agama Islam (PAI) di sekolah umum juga mengikuti Kurikulum 2013 yang telah dicanangkan tersebut. Pelaksanaan pembelajaran PAI di sekolah-sekolah proyek percontohan Kurikulum 2013 dapat menjadi bahan evaluasi bagi pelaksanaan Kurikulum 2013 untuk mata pelajaran PAI untuk mengetahui faktor pendukung dan kendala dalam pelaksanaannya. Mengingat urgensi pelaksanaan kurikulum 2013 khususnya untuk Pendidikan Agama Islam yang sedikit berbeda pendekatannya dibanding kurikulum sebelumnya, maka menjadi hal yang penting untuk mengetahui penerapan kurikulum 2013 yang telah dilaksanakan di beberapa sekolah. Hal ini sangat berguna untuk mengetahui berbagai hal terkait dengan pelaksanaan Kurikulum 2013 untuk menjadi bahan evaluasi bagi pengambil kebijakan dan pelaksana (tenaga kependidikan) untuk membuat strategi dalam mengatasi kendala-kendala yang dihadapi. Untuk itulah buku ini hadir di hadapan pembaca dengan menawarkan artikel-artikel mengenai pelaksanaan Kurikulum 2013 mata pelajaran PAI pada SMA di Jawa Tengah.

Buku ini menampilkan enam artikel terkait dengan pelaksanaan Kurikulum 2013 pada mata pelajaran PAI pada SMA di Jawa Tengah dan satu artikel tamu Kurikulum 2013. Kajian pelaksanaan Kurikulum 2013 mata pelajaran PAI secara umum membahas mengenai kesiapan sekolah beserta perangkatnya untuk melaksanakan kurikulum 2013 khususnya mata pelajaran PAI. Buku ini juga membahas mengenai kesesuaian dalam pelaksanaannya terhadap standar isi, standar proses dan kurikulum yang telah ditetapkan dalam peraturan menteri pendidikan dan kebudayaan, dan untuk melihat faktor pendukung dan faktor penghambat dalam pelaksanaan Kurikulum 2013 khususnya pada mata pelajaran PAI.

Pembahasan mengenai kesiapan sekolah dapat memberikan gambaran mengenai kondisi sekolah yang telah melaksanakan Kurikulum 2013 dalam pelaksanaan pembelajaran. Sedangkan kesesuaian pelaksanaan adalah menggambarkan tingkatan pencapaian dalam pelaksanaan dibandingkan dengan standar yang telah ditetapkan dalam Peraturan Menteri Pendidikan dan Kebudayaan mengenai standar isi, standar proses, dan kurikulum. Sementara faktor pendukung dan penghambat menggambarkan beberapa realitas dalam pelaksanaan di lapangan sehubungan dengan diberlakukannya "kurikulum baru" ini.

Artikel-artikel yang ada dalam buku di hadapan pembaca ini hadir tidak secara tiba-tiba, tetapi telah melalui rentetan proses yang tidak sebentar. Dimulai dari pengumpulan naskah yang merupakan hasil penelitian tahun 2015 kemudian dilakukan pengkoreksian oleh tim internal. Selanjutnya naskah tersebut direvisi oleh penulisnya masing-masing setelah menerima masukan dari tim internal. Kemudian setelah direvisi oleh penulis dilakukan lagi koreksi oleh Tim Penjamin Mutu Internal Peneliti (TPMIP) dan dikembalikan lagi kepada penulis untuk sekali lagi dilakukan koreksi. Koreksi terakhir dilakukan oleh editor TPMIP sebelum akhirnya diserahkan ke penerbit. Langkah-langkah editing dan koreksi yang berkali-kali tersebut dimaksudkan agar artikel-artikel yang tersaji di hadapan pembaca ini menjadi bacaan yang berkualitas dan menarik untuk.

Akhirnya kami berharap agar buku ini dapat memberikan manfaat baik bagi siapa saja yang terlibat dalam pelaksanaan Kurikulum 2013, pemerhati pendidikan, dan lebih luas lagi bagi pengembangan ilmu pengetahuan. 
Kata Pengantar Ketua Panitia .................................................................................................. iii

Kata Pengantar Kepala Balai Litbang Agama Semarang ………............................................... iv

Kata Pengantar Editor ........................................................................................................... vi

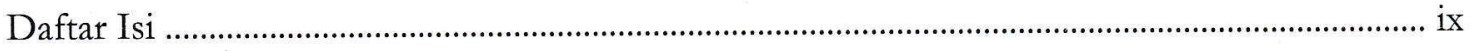

PELAKSANAAN KURIKULUM 2013PADA JENJANG PENDIDIKAN

MENENGAH (Studi Evaluasi terhadap Proses Pembelajaran Mata Pelajaran

Pendidikan Agama Islam (PAI) pada SMAN 1 Godean Sleman)

Umi Muzayanah

1

EVALUASI PELAKSANAAN KURIKULUM 2013 MATA PELAJARAN PAI

DAN BUDI PEKERTI DI SMAN 1 BANTUL

Siti Muawanah

21

EVALUASI PELAKSANAAN KURIKULUM 2013 PADA MATA PELAJARAN

PAI DAN BUDI PEKERTI PADA SMA NEGERI 1 WONOSARI KABUPATEN

GUNUNGKIDUL

A.M. Wibowo

EVALUASI PELAKSANAAN KURIKULUM 2013 MATA PELAJARAN

PENDIDIKAN AGAMA ISLAM DI SMAN 1 KUDUS

Nugroho Eko Atmanto

EVALUASI PELAKSANAAN KURIKULUM 2013 (Studi Pada SMA Negeri

Di Kabupaten Banyumas)

Mulyani Mudis Taruna

EVALUASI PELAKSANAAN KURIKULUM 2013 MATA PELAJARAN

PENDIDIKAN AGAMA ISLAM (Studi pada SMA N I Magelang)

Yusriati

IMPLEMENTASI KURIKULUM 2013 DALAM PROSES PEMBELAJARAN

Prof. Dr. H. Achmad Slamet, M.Si.

PELAKSANAAN PERATURAN PEMERINTAH TENTANG STANDAR

PENILAIAN PENDIDIKAN DI MADRASAH ALIYAH NEGERI III

YOGYAKARTA

Agus Mujiono 


\title{
PELAKSANAAN KURIKULUM 2013 \\ PADA JENJANG PENDIDIKAN MENENGAH \\ (Studi Evaluasi terhadap Proses Pembelajaran Mata Pelajaran Pendidikan Agama \\ Islam (PAI) pada SMAN 1 Godean Sleman)
}

\author{
Oleh \\ Umi Muzayanah \\ Balai Litbang Agama Semarang \\ Email: umimoza78@gmail.com
}

\begin{abstract}
ABSTRAK
Pelaksanaan Kurikulum 2013 dalam perjalanannya menuai pro dan kontra terkait kesiapan dari berbagai elemen penyelenggara pendidikan. Kontroversi tersebut berujung pada penghentian pelaksanaan Kurikulum 2013 kecuali pada beberapa sekolah yang ditunjuk. Masih diberlakukannnya Kurikulum 2013 pada sekolah umum yang telah ditunjuk memerlukan pemantauan dan evaluasi secara berkala dari berbagai pihat yang terkait. Penelitian ini bertujuan untuk mengevaluasi pelaksanaan Kurikulum 2013 di SMAN 1 Godean, dengan fokus evaluasi pada pelaksanaan pembelajaran PAI dan Budi Pekerti. Hasil penelitian menunjukkan bahwa pelaksanaan pembelajaran PAI dan Budi Pekerti pada SMAN 1 Godean dilihat dari aspek konteks, input, proses, dan produk belum sepenuhnya sesuai dengan standar isi, standar proses, dan standar penilaian. Hal ini dikarenakan masih minimnya pelatihan Kurikulum 2013 yang diperoleh guru PAI, khususnya terkait teknis pelaksanaan Kurikulum 2013 yang sesuai dengan dokumen standar.
\end{abstract}

Kata Kunci: Evaluasi, Kurikulum 2013, CIPP, PAI

\section{PENDAHULUAN}

Kurikulum 2013 sebagai pengganti Kurikulum 2006 (atau yang sering disebut sebagai KTSP) dilaunching pada tahun pelajaran 2013/2014 di beberapa sekolah umum yang ditunjuk sebagai pilot project. Perbedaan mendasar antara Kurikulum 2013 dengan kurikulum sebelumnya diantaranya adalah adanya kontribusi seluruh mata pelajaran terhadap pembentukan sikap, keterampilan, dan pengetahuan. Proses pembelajaran yang menggunakan pendekatan saintifik juga menjadi pembeda Kurikulum 2013 dengan kurikulum sebelumnya.

Seiring berjalannya Kurikulum 2013 yang dilaksanakan oleh seluruh sekolah dan madrasah pada tahun pelajaran 2014/2015, terjadi pergantian pemerintahan dari masa Kabinet Indonesia Bersatu Jilid 2 kepada Kabinet Kerja yang resmi dilantik tanggal 20 Oktober 2014. Kurikulum 2013 yang notabene merupakan produk pemerintahan terdahulu mendapat perhatian serius dari pemerintahan baru melalui Kementerian Pendidikan dan Kebudayaan. Munculnya kontroversi terkait Kurikulum 2013 menjadi dasar yang kuat untuk melakukan evaluasi terhadap pemberlakuan Kurikulum 2013 di seluruh sekolah.

Hasil evaluasi terhadap pemberlakuan Kurikulum 2013 menghasilkan tiga keputusan yang tertuang dalam surat Menteri Pendidikan dan Kebudayaan RI Nomor: 179342/MPK/KR/2014 Tanggal 5 Desember 2014 tentang Pelaksanaan Kurikulum 2013. Pertama, menghentikan Kurikulum 2013 untuk sekolah yang baru menyelenggarakan selama satu semester dan kembali menggunakan Kurikulum 2006. Kedua, melanjutkan Kurikulum 2013 bagi sekolah yang telah melaksanakannya selama dua tiga semester sebagai sekolah percontohan. Khusus bagi sekolah yang merasa belum sanggup melaksanakannya bisa melaporkannya ke Kementerian Pendidikan. Ketiga, Kurikulum 2013 diserahkan pada Pusat Kurikulum dan Perbukuan (Puskurbuk) serta Unit Implementasi Kurikulum (UIK). Dengan begitu, perbaikan terhadap Kurikulum 2013 tidak berhenti ("Ini Keputusan Hasil Evaluasi Kurikulum 2013", 2014). 


\section{Prosiding: Evaluasi Kurikulum 2013 Mata Pelajaran Pendidikan Agama Islam Pada SMA di Jawa Tengah Dan D.I.Yogyakarta}

Evaluasi 2013 belum bisa dilakukan secara menyeluruh mengingat pelaksanaan baru berjalan lima semester atau dua setengah tahun. Namun demikian, evaluasi tahap awal bisa dilakukan dengan melakukan evaluasi terhadap proses pembelajaran. Penelitian ini dilakukan sebagai upaya memberikan evaluasi terhadap proses pembelajaran yang sesuai dengan Kurikulum 2013.

Evaluasi pelaksanaan Kurikulum 2013 pada mapel PAI pada penelitian ini terbatas pada evaluasi terhadap proses pembelajaran PAI pada SMAN yang telah ditunjuk pemerintah untuk melanjutkan penerapan Kurikulum 2013, dengan kriteria telah melaksanakan Kurikulum 2013 selama tiga semester. Tulisan ini merupakan hasil evaluasi terhadap pelaksanaan Kurikulum 2013 pada proses pembelajaran PAI di SMAN 1 Godean, yang merupakan salah satu SMAN di Yokyakarta yang telah ditunjuk oleh pemerintah untuk melanjutkan pelaksanaan Kurikulum 2013.

Secara teoritis, penelitian ini berguna sebagai referensi ilmiah bagi penelitian yang bersifat evaluatif, khususnya dalam kajian evaluasi pelaksanaan Kurikulum 2013. Secara praktis, penelitian ini berguna bagi pemerintah, dalam hal ini Kementerian Agama dan Kementerian Pendidikan dan Kebudayaan sebagai informasi hasil evaluasi terhadap pelaksanaan Kurikulum 2013 khususnya proses pembelajaran PAI. Informasi hasil penelitian tersebut dapat dijadikan bahan dalam perumusan kebijakan terkait dengan pelaksanaan Kurikulum 2013 di SMA.

Penerapan Kurikulum 2013 menekankan pada dimensi pedagogik modern dalam pembelajaran, yaitu menggunakan pendekatan ilmiah (scientific approach). Pendekatan ilmiah dalam pembelajaran sebagaimana dimaksud meliputi mengamati, menanya, mencoba, mengolah, menyajikan, menyimpulkan, dan mencipta untuk semua mata pelajaran. Pada Kurikulum 2013, sudah tidak lagi menggunakan istilah standar kompetensi, akan tetapi berganti istilah menjadi kompetensi inti. Kompetensi inti merupakan gambaran mengenai kompetensi utama yang dikelompokkan ke dalam aspek sikap, pengetahuan, dan keterampilan (afektif, kognitif, dan psikomotor) yang harus dipelajari peserta didik untuk suatu jenjang sekolah, kelas dan mata pelajaran (Astuti, 2013).

Metode scientific, selanjutnya ditulis saintifik, diperkenalkan dalam dunia pendidikan di Amerika pada akhir abad ke-19. Pembelajaran dengan pendekatan saintifik adalah pembelajaran yang menekankan pada pemberian pengalaman secara langsung baik menggunakan observasi, eksperimen maupun cara yang lainnya, sehingga realitas yang akan berbicara sebagai informasi atau data yang diperoleh selain valid juga dapat dipertanggungjawabkan ( $\mathrm{Su}$ jarwanta, 2012:75). Penerapan metode saintifik dalam proses pembelajaran memberikan peluang yang besar bagi siswa untuk terlibat secara aktif, kreatif, dan inovatif dalam proses pembelajaran.

Varelas and Michael Ford sebagaimana dikutip oleh Atsnan dan Rahmita (2013:430) menjelaskan bahwa metode saintifik memudahkan guru atau pengembang kurikulum untuk memperbaiki proses pembelajaran. Hal ini dapat dilakukan dengan memecah proses ke dalam langkah-langkah atau tahapan-tahapan secara terperinci yang memuat instruksi untuk siswa melaksanakan kegiatan pembelajaran.

Kurikulum 2013 lebih mengacu pada pendekatan Dyers (2011) yang mengedepankan kreativitas dibanding dengan kecerdasan. Menurut Dyers sebagaimana dikutip oleh Widodo (2013: 587-588) pembelajaran berbasis kecerdasan tidak akan memberikan hasil signifikan (hanya peningkatan 50\%) dibandingkan yang berbasis kreativitas (sampai 200\%). Realitas ini memberikan banyak peluang kepada guru untuk meningkatkan kreativitas siswa.

Dalam penerapan pendekatan saintifik, terdapat beberapa karakteristik menarik yang menjadi dasar dari pengembangan Kurikulum 2013 di Indonesia. Pertama, pembelajaran dengan pendekatan saintifik berpusat pada siswa. Hal ini akan memberikan peluang siswa untuk terlibat aktif dalam proses pembelajaran. Kedua, melibatkan keterampilan proses sains dalam mengonstruksi konsep, hukum atau prinsip. Ketiga, melibatkan proses-proses 


\section{Prosiding: Evaluasi Kurikulum 2013 Mata Pelajaran Pendidikan Agama Islam Pada SMA di Jawa Tengah Dan D.I.Yogyakarta}

program untuk dapat digunakan sebagai dasar membuat keputusan, menyusun kebijakan, maupun menyusun program selanjutnya.

Arikunto (2010;41-48) menjelaskan beberapa model yang dapat dikembangkan dalam melakukan evaluasi, yaitu Goal Oriented Evaluation Model, Goal Free Evaluation Model, Formatif Summatif Evaluation Model, Countenance Evaluation Model, Responsif Evaluation Model, SSE-UCLA Evaluation Model, Discrepancy Model, dan CIPP Evaluation Model (Context Input Process Product). Model terakhir banyak menjadi rujukan para pemerhati pendidikan untuk melakukan evaluasi terhadap program-program pendidikan.

Model CIPP yang dikembangkan oleh Stufflebeam merupakan model evaluasi yang paling banyak dikenal dan diterapkan olch para evaluator (Arikunto, 2010: 45). Model CIPP memberikan peluang informasi yang lebih luas terhadap program yang dievaluasi. Hal ini karena model ini mencakup empat sasaran evaluasi, yaitu konteks, masukan, proses, dan hasil. Keempat dimensi evaluasi model CIPP didefinisikan sebagai berikut (Sudjana dan Ibrahim, 2004:246):

a. Context, situasi atau latar belakang yang mempengaruhi jenis-jenis tujuan dan strategi pendidikan yang akan dikembangkan dalam sistem yang bersangkutan.

b. Input, sarana/modal/bahan dan rencana strategis yang ditetapkan untuk mencapai tujuan pendidikan.

c. Process, pelaksanaan strategi dan penggunaan sarana/modal/bahan di dalam kegiatan nyata di lapangan.

d. Product, hasil yang dicapai baik selama maupun pada akhir pengembangan sistem pendidikan yang bersangkutan.

Pemilihan model evaluasi tidak terlepas dari kelebihan dan kekurangan yang dimilikinya. Menurut Widoyoko (2012: 184), model evaluasi CIPP memiliki kelebihan dibanding model evaluasi yang lain. Kelebihan yang dimiliki oleh CIPP diantaranya adalah hasil evaluasi lebih komprehensif, karena sasaran evaluasi mencakup konteks, masukan, proses, dan hasil. Keterbatasan yang dimiliki CIPP adalah kebutuhan waktu yang cukup lama karena melibatkan banyak pihak dalam melakukan evaluasi konteks, masukan, proses, dan hasil.

\section{METODE PENELITIAN}

Penelitian ini merupakan penelitian yang bersifat evaluatif dengan menggunakan model evaluasi CIPP. Metode penelitian yang digunakan dalam penelitian ini adalah kualitatif deskriptif. Pendekatan kualitatif digunakan untuk memperoleh data tentang deskripsi penerapan Kurikulum 2013 pada mata pelajaran PAI. Teknik pengumpulan data menggunakan wawancara, studi dokumentasi, dan observasi. Wawancara digunakan untuk menggali data primer tentang pelaksanaan pembelajaran PAI yang mengacu pada Kurikulum 2013. Sasaran interviewee adalah Dinas Pendidikan, Kementerian Agama, kepala sekolah, guru PAI, peserta didik, dan pihak terkait lainnya. Studi dokumentasi digunakan untuk mengumpulkan data yang terkait dengan profil sekolah, dokumen perencanaan pembelajaran, pelaksanaan pembelajaran, sampai pada dokumen penilaian hasil pembelajaran. Observasi langsung digunakan untuk memperoleh data dari sudut pandang peneliti berdasarkan hasil pengamatan langsung terhadap proses pembelajaran PAI beserta model pembelajaran yang digunakan.

Penelitian ini dilakukan pada SMA N 1 Godean, Sleman, Yogyakarta yang sampai saat ini menerapkan Kurikulum 2013. Fokus penelitian adalah pelaksanaan Kurikulum 2013 pada mata pelajaran PAI. Untuk melakukan evaluasi dengan model CIPP, perlu diidentifikasi terlebih dahulu komponen-komponen evaluasi beserta sasaran subjeknya, seperti pada tabel 1 . 


\section{Prosiding: Evaluasi Kurikulum 2013 Mata Pelajaran Pendidikan Agama Islam Pada SMA di Jawa Tengah Dan D.I.Yogyakarta}

SMAN 1 Godean merupakan satu dari tujuh SMAN di Kabupaten Sleman yang melaksanakan Kurikulum 2013 sejak pertama kali kurikulum ini dilaunching tahun 2013. Sekolah yang mengusung visi "Berakhlak mulia, Unggul dalam Prestasi, Menguasai IPTEK, dan Berwawasan Global” ini memiliki siswa sebanyak 540 siswa yang terbagi menjadi 18 rombel, dimana setiap jenjang kelas terdiri dari 6 rombel. Seluruh jenjang kelas di SMAN 1 Godean, mulai jenjang kelas X, XI, sampai XII sudah melaksanakan proses pembelajaran berdasarkan Kurikulum 2013.

Perbandingan siswa laki-laki dengan perempuan cukup tajam, yakni mencapai rasio 1:3, dimana jumlah siswa laki-laki 142 anak dan siswa perempuan berjumlah 398 siswa. Dilihat dari agama yang dipeluk, mayoritas siswa beragama Islam, yakni mencapai 87,78\%, disusul siswa beragama Katolik 10\%, dan siswa beragama Kristen 2,22\%. Pilihan program yang disediakan di SMAN 1 Godean hanya ada dua, yaitu IPA dan IPS. Siswa yang tergabung dalam kelas dengan program pilihan IPA berjumlah 352 siswa, sedangkan yang masuk pada program pilihan IPS berjumlah 188 siswa.

Guru yang mengajar di SMAN 1 Godean berjumlah 43 orang, yang terdiri dari 39 guru pengajar tetap dan 4 guru yang menginduk pada sekolah lain. Dari 39 guru yang mengajar di SMAN 1 Godean, 34 diantaranya berstatus PNS, sedangkan lima guru lainnya berstatus honorer. Dilihat dari latar belakang pendidikan, 37 orang guru memiliki ijazah tertinggi S1, sedangkan dua orang sudah menyelesaikan pendidikan S2, diantaranya adalah kepala sekolah yang merupakan guru PKn. Guru yang mengabdi di sekolah ini belum seluruhnya lulus ujian sertifikasi.

\section{Pelaksanaan Kurikulum 2013 pada Mapel PAI ditinjau dari kesiapan guru}

Sesuai dengan tuntutan Kurikulum 2013, PAI sebagai salah satu mata pelajaran wajib memiliki alokasi waktu 3 jam pelajaran (JP). Dalam praktiknya, pembelajaran PAI tidak seluruhnya dilakukan $3 \mathrm{JP}$ secara sekaligus, ada beberapa kelas yang memperoleh pembelajaran PAI 2 JP dan 1 JP pada hari yang berbeda. Hal ini dilakukan untuk memberikan peluang kepada guru dan siswa non Islam agar melaksanakan pembelajaran pendidikan agamanya.

Guru PAI berjumlah dua orang yang statusnya sebagai guru tetap, keduanya sudah cukup lama mengabdi sebagai guru PAI, yaitu 32 tahun dan 26 tahun. Beban mengajar guru PAI dalam satu minggu masing-masing 27 jam pelajaran, dimana keduanya mengajar di seluruh jenjang kelas yang ada. Artinya, satu guru mengajar di kelas X, XI, dan XII, dengan pembagian rombel yang seimbang dengan guru PAI yang lain.

Dalam rangka peningkatan wawasan dan kompetensi guru PAI dalam pelaksanaan Kurikulum 2013, kedua guru PAI telah mengikuti sosialisasi dokumen tentang standar yang diselenggarakan oleh Kementerian Agama Kabupaten Sleman. Selain itu, salah satu guru PAI juga pernah memperoleh sosialisasi dari Kemendikbud tentang Kurikulum 2013 yang berlangsung selama tiga hari di UNY. Peserta sosialisasi tersebut adalah seluruh SMA pelaksana Kurikulum 2013 di Provinsi DIY, dimana masing-masing sekolah mengirimkan satu utusan guru PAI. Selain itu, pelatihan Kurikulum 2013 juga diperoleh dalam bentuk IHT atau pendampingan oleh Direktorat Pembinaan SMA Kemendikbud yang secara rutin dilakukan setiap awal tahun, dengan melibatkan seluruh guru di sekolah. Sampai saat ini, IHT sudah dilakukan selama 5 kali sejak Kurikulum 2013 diberlakukan.

Dokumen Rencana Pelaksanaan Pembelajaran (RPP) disusun dengan mengacu pada pedoman penyusunan RPP yang berbasis Kurikulum 2013 yang diadopsi dari silabus PAI dan Budi Pekerti. Komponen RPP sudah sesuai dengan Permendikbud 65 Tahun 2013. Langkah-langkah pembelajaran dilakukan melalui tahapan pendahuluan, kegiatan inti, dan penutup. Tahap inti sudah memuat lima sintak yang merupakan representasi dari metode saintifik. RPP yang mereka susun dikembangkan oleh MGMP, yang selanjutnya disempurnakan oleh tim guru PAI sekolah. 


\section{Prosiding: Evaluasi Kurikulum 2013 Mata Pelajaran Pendidikan Agama Islam Pada SMA di Jawa Tengah Dan D.I.Yogyakarta}

Pencapaian KD terkait tatacara penyelenggaraan jenazah didekati dengan dua strategi pembelajaran pada dua kali pertemuan. Pertemuan pertama dilakukan dengan strategi info search dan diskusi serta tanya jawab, sedang pertemuan kedua siswa diberi penugasan untuk membuat video tentang tatacara penyelenggaraan jenazah. Dengan alokasi waktu 3 JP dalam satu kali pertemuan, sangat memungkinkan bagi siswa untuk melakukan kegiatan 5M selama proses pembelajaran.

c. Khutbah, Tabligh, dan Dakwah

Materi ini disampaikan pada pembelajaran kelas XI dengan alokasi waktu pembelajaran 4 x 3 JP. KD yang akan dicapai dalam materi pembelajaran ini ada tiga KD, yaitu menerapkan ketentuan syariat Islam dalam pelaksanaan khutbah, tabligh, dan dakwah di masyarakat (KD 1.5), memahami pelaksanaan khutbah, tabligh, dan dakwah (KD 3.10), dan mempraktikkan khutbah, tabligh, dan dakwah (KD 4.10). Dalam pencantuman KD masih ada yang belum sesuai dengan Permendikbud Nomor 59 Tahun 2014, yaitu dengan masih menuliskan mempraktikkan khutbah, tabligh, dan dakwah sebagai KD 4.12. Hal ini karena penyusunan RPP masih mengacu pada Permendikbud Nomor 69 Tahun 2013. Padahal pada Nomor 59 Tahun 2014 KD 4.12 adalah mendeskripsikan perkembangan Islam pada masa modern (1800-sekarang).

Pencapaian KD pembelajaran yang direncanakan dalam RPP menggunakan strategi pembelajaran Synergetic teaching pada pertemuan pertama. Selanjutnya guru menggunakan strategi pembelajaran card short pada pertemuan kedua, strategi pembelajaran who is in the class pada pertemuan ketiga dan keempat. Strategi pembelajaran koperatif yang dipilih sudah sesuai dengan KD yang ingin dicapai dalam empat kali pertemuan tersebut.

\section{d. Memahami Hukum Islam tentang Hukum Keluarga}

Materi ini disampaikan guru PAI pada pembelajaran kelas XII, dengan alokasi pertemuan $2 \times 3$ JP. KD yang akan dicapai dalam proses pembelajaran selama 2 kali pertemuan tersebut adalah menerapkan ketentuan syariat Islam dalam melaksanakan pernikahan (KD 1.3), memahami ketentuan pernikahan dalam Islam (KD 3.6), memahami hak dan kedudukan wanita dalam keluarga berdasarkan hukum Islam (KD 3.7), memperagakan tata cara pernikahan dalam Islam (KD 4.6), dan menyajikan hak dan kedudukan wanita dalam keluarga berdasarkan hukum Islam (KD 4.7). Kelima KD yang akan dicapai dalam pembelajaran seluruhnya sudah sesuai dengan Permendikbud Nomor 59 Tahun 2014, baik dari kodefikasi KD maupun dari narasi KD tersebut.

Strategi pembelajaran yang digunakan adalah diskusi, tanya jawab, dan info search pada setiap pertemuan, yang disertai dengan simulasi pernikahan oleh siswa. Meskipun strategi pembelajaran melalui diskusi dan tanya jawab, jika dilakukan secara kreatif dan maksimal, maka pendekatan saintifik dapat tercapai dan tuntutan KD dapat tercapaisecara tuntas.

\section{e. Rahmat Islam di Nusantara}

Materi Rahmat Islam di Nusantara merupakan materi yang diajarkan pada kelas XII, dengan alokasi waktu $2 \times 3$ JP. KD yang akan dicapai melalui penyampaian materi ini adalah memahami strategi dakwah dan perkembangan Islam di Indonesia (KD 3.9) dan mendeskripsikan strategi dakwah dan perkembangan Islam di Indonesia (KD 4.9). Kedua KD yang tercantum dalam RPP dan sudah sesuai dengan Permendikbud Nomor 59 Tahun 2014.

Strategi pembelajaran guna mencapai KD di atas dilakukan dengan ceramah, group resume, dan gallery walk pada pertemuan pertama, sedangkan pada pertemuan kedua strategi yang digunakan adalah dengan metode ceramah dan concept mapping. Penerapan metode pembelajaran ceramah yang direncanakan dalam RPP tidak ses- 
uai dengan tuntutan pembelajaran berbasis saintifik, dimana pembelajaran dilakukan dengan berpusat pada siswa, bukan lagi guru yang mendominasi.

Dari paparan evaluasi konteks yang mencakup KD dan penerapan pendekatan saintifik, belum seluruhnya sesuai dengan standar yang ditetapkan. Hal ini ditunjukkan dengan masih adanya KD yang mengacu pada Permendikbud Nomor 69 Tahun 2013, yang semestinya sudah mengacu pada Permendikbud Nomor 59 Tahun 2014. Demikian juga dengan strategi pembelajaran yang digunakan dalam menerapkan pendekatan saintifik juga masih belum sempurna, ditandai dengan masih adanya metode ceramah dalam pencapaian KD. Metode ceramah yang masih disematkan guru dalam RPP menunjukkan bahwa pendekatan saintifik yang belum sepenuhnya dilakukan.

\section{Evaluasi Input Pembelajaran}

Input dalam pelaksanaan Kurikulum 2013 pada proses pembelajaran PAI tidak terlepas dari dukungan Disdikpora Kabupaten Sleman, Kemenag Kabupaten Sleman, dan SMAN 1 Godean. Ketersediaan dokumen tentang standar pelaksanaan Kurikulum 2013 sudah 100\% dipenuhi oleh seluruh instansi terkait, dengan tahun perolehan sama dengan tahun terbit peraturan tersebut. Hal ini menunjukkan bahwa respon pihak terkait terhadap dinamika Kurikulum 2013 sangat cepat dan inovatif, karena beberapa dokumen diperoleh dengan upaya mencari sendiri. Input pelaksanaan Kurikulum 2013 dari segi ketersediaan dokumen standar sudah sangat bagus, karena dokumen yang tersedia lengkap dan cepat dalam hal perolehannya.

Guru agama yang pembinaannya masuk pada wilayah kewenangan Kementerian Agama masih banyak yang belum memperoleh sosialisasi Kurikulum 2013 secara langsung. Guru agama di bawah Kementerian Agama Kabupaten Sleman yang telah memperoleh pelatihan Kurikulum 2013 sebagai guru inti hanya 6\%, guru sasaran mencapai 30,3\%, sedangkan guru agama yang terlatih sebagai instruktur nasional belum ada sama sekali. Namun demikian, informasi Kurikulum 2013 bagi guru agama bisa diperoleh dengan cara pengimbasan dan juga IHT yang rutin diadakan di sekolah. Dukungan Kementerian Agama sebagai instansi yang berwenang membina guru agama lebih pada penyediaan narasumber kegiatan sosialisasi Kurikulum 2013.

Dengan demikian dapat dikatakan bahwa pelaksanaan Kurikulum 2013 mapel PAI dari sisi input masih kurang baik. Pelatihan-pelatihan Kurikulum 2013 masih harus dilakukan dengan sasaran seluruh guru PAI, khususnya pelatihan yang diselenggarakan oleh Kementerian Agama.

\section{Evaluasi Proses Pembelajaran}

Evaluasi proses pembelajaran tidak terlepas dari perencanaan pembelajaran dan proses pembelajaran yang dilakukan oleh guru agama. Evaluasi perencanaan pembelajaran dilakukan dengan melakukan telaah terhadap RPP yang dikembangkan oleh guru PAI. Berdasarkan Permendikbud Nomor 59 Tahun 2015, KD kelompok mata pelajaran PAI dan Budi Pekerti cukup banyak yang harus dipenuhi oleh guru dan siswa. KD pada pembelajaran selama satu tahun untuk kelas X sebanyak sepuluh KD, kelas XI sebanyak dua belas KD, dan kelas XII sebanyak sepuluh KD. Seluruh KD tersebut harus tuntas melalui pembelajaran PAI dan Budi Pekerti yang dialokasikan 3 JP setiap minggunya.

Evaluasi proses pembelajaran setelah terlebih dahulu melakukan telaah terhadap dokumen RPP, dilanjutkan dengan evaluasi terhadap pelaksanaan proses pembelajaran PAI dan Budi Pekerti. Evaluasi ini bertujuan untuk melihat secara langsung praktik pembelajaran yang dilakukan oleh Guru PAI sebagai implementasi dari RPP yang telah ia susun. Evaluasi dilakukan dengan melihat kesesuaian antara proses pembelajaran dengan RPP yang disusun, 


\section{Prosiding: Evaluasi Kurikulum 2013 Mata Pelajaran Pendidikan Agama Islam Pada SMA di Jawa Tengah Dan D.I.Yogyakarta}

serta kesesuaian keduanya dengan Permendikbud Nomor 64 Tahun 2013 tentang Standar Isi, Permendikbud Nomor 65 Tahun 2013 tentang Standar Proses, dan Permendikbud Nomor 66 Tahun 2013 tentang Standar Penilaian.

Evaluasi terhadap RPP dan pelaksanaan proses pembelajaran tidak dilakukan terhadap seluruh KD yang menjadi tanggung jawab guru. Evaluasi hanya dilakukan terhadap lima KD yang diajarkan tepat bersamaan dengan waktu penelitian berlangsung. Pengamatan terhadap proses pembelajaran dari lima KD tersebut dilakukan terhadap enam proses pembelajaran, tiga pembelajaran yang dilakukan oleh Pak Suparyanta dan tiga pembelajaran yang dilakukan oleh Ibu Sri Handayani. Pengamatan dilakukan pada seluruh jenjang kelas, dimana masing-masing jenjang kelas dilakukan pengamatan sebanyak dua kali dengan guru yang berbeda.

Hasil telaah terhadap RPP pada lima KD mapel PAI dan Budi Pekerti ditemukan beberapa ketidaksesuaian dengan dokumen standar, diantaranya adalah:

a. Identitas sekolah pada beberapa RPP belum tercantum secara lengkap. Dalam RPP hanya tertera SMA, yang seharusnya adalah SMAN 1 Godean.

b. Penulisan alokasi waktu tidak sesuai dengan jumlah pertemuan kegiatan pembelajaran. Misalnya saja alokasi waktu tertera 4 x $3 \mathrm{JP}$, namun di tujuan pembelajaran dan kegiatan pembelajaran hanya tertera 3 kali pertemuan.

c. Materi pembelajaran yang disajikan belum sesuai dengan standar proses, karena hanya mencantumkan judul tema pembelajaran (3 poin), belum mencakup fakta, konsep, prinsip, dan prosedur yang relevan.

d. Metode pembelajaran sebagian belum sesuai dengan standar proses, yaitu masih adanya metode ceramah yang bertentangan dengan prinsip partisipasi aktif siswa dan pembelajaran berpusat pada siswa.

e. Penulisan kompetensi inti yang merupakan bagian awal dari RPP guru mengacu pada Permendikbud Nomor 69 Tahun 2013, bukan pada standar isi pada Permendikbud Nomor 64 Tahun 2013.

f. Penulisan kompetensi dasar sebagian belum sesuai, ditunjukkan dengan adanya penulisan KD yang masih mengacu pada Permendikbud Nomor 69 Tahun 2013, bukan Permendikbud Nomor 59 Tahun 2014.

Hasil telaah RPP terhadap lima KD menunjukkan bahwa penyusunan RPP mata pelajaran PAI belum sepenuhnya sesuai dengan standar isi, standar proses, dan standar penilaian. Dengan kata lain, penyusunan RPP masih perlu diperbaiki dan disempurnakan, karena keberhasilan pelaksanaan pembelajaran PAI yang sesuai dengan tuntutan Kurikulum 2013 akan sangat bergantung kepada RPP yang disusun oleh guru.

Selain melakukan evaluasi terhadap RPP yang disusun guru, evaluasi proses pembelajaran juga dilakukan dengan melakukan pengamatan langsung terhadap proses pembelajaran yang diampu oleh kedua guru PAI. Hasil evaluasi proses pembelajaran melalui pengamatan terhadap lima materi pokok dapat dipaparkan sebagai berikut.

\section{a. Al-Quran Hadits Pedoman Hidupku}

Pembelajaran materi Al-Quran Hadits Pedoman Hidupku yang diampu oleh Bapak Suparyanta dilaksanakan pada tanggal 27 Oktober 2015 pada jam pelajaran ke 4, 5, dan 6. Waktu yang dialokasikan adalah tiga kali pertemuan, dan pengamatan dilakukan pada pertemuan ke-2. Pertemuan ke-1 digunakan untuk menjelaskan materi, dimana siswa diberi tugas secara berkelompok untuk membuat makalah tentang Sumber Hukum Islam, dengan substansi penugasan yang sama. Pada pertemuan ke-2, siswa secara berkelompok diberi tugas untuk melakukan presentasi terhadap makalah yang telah dibuat. Cakupan presentasi dibatasi pada satu bahasan saja, misalnya saja kelompok 1 mempresentasikan materi tentang Al-Quran, kelompok 2 tentang Hadits, dan seterusnya. Presentasi 
dilakukan dengan menggunakan media laptop dan LCD. Selama presentasi berlangsung, siswa lain boleh mengajukan pertanyaan ataupun tanggapan dari hasil kerja kelompok presenter. Pada aktivitas ini hanya sedikit siswa yang terlihat aktif terlibat.

Dari pertemuan ke-1 dan ke-2, keduanya tidak sesuai dengan skenario pembelajaran yang ada di RPP. Dalam skenario pembelajaran, pertemuan ke-1 tertulis metode yang digunakan adalah Student Created Case Studies, sementara pada realitas pembelajaran, siswa diberi tugas kelompok untuk membuat makalah. Sumber makalah yang diacu siswa berasal dari internet yang diambil secara copy paste, sehingga perlu mendapat kawalan yang ketat dari guru untuk memastikan kebenaran sumber tersebut. Namun pada kenyataannya, guru belum melakukan klarifikasi secara optimal terkait sumber-sumber yang diacu oleh siswa, khususnya yang bersumber dari internet.

Pada skenario pembelajaran pertemuan ke-2, tertulis pembelajaran menggunakan metode Reading Guide, dimana siswa mengamati dengan membaca hand out yang diberikan guru. Selanjutnya beberapa siswa diminta sebagai voluntir untuk menyampaikan isi bacaan, seluruh siswa menyiapkan pertanyaan dan juga siswa harus siap memberikan jawaban. Namun pada realitas pembelajaran, pertemuan ke-2 digunakan untuk melakukan presentasi terhadap hasil kerja kelompok berupa makalah tentang Sumber Hukum Islam. Dalam kegiatan ini pun tidak berjalan secara optimal, karena tidak seluruh siswa terlibat secara aktif dalam proses pembelajaran.

Jika didasarkan pada standar proses, pelaksanaan proses pembelajaran tersebut belum sesuai dengan Permendikbud Nomor 65 Tahun 2013. Langkah-langkah pembelajaran pada kegiatan pendahuluan misalnya, tidak seluruhnya dilakukan oleh guru, dan kalau pun ada, tidak dilakukan pada setiap pertemuan. Misalnya saja pada kegiatan menyiapkan siswa secara psikis dan fisik untuk mengikuti proses pembelajaran tidak dilakukan guru secara rutin. Pada pengamatan kelas yang dilakukan, guru cenderung lebih to the point pada apa yang sudah ditugaskan pada pertemuan sebelumnya.

Metode pembelajaran yang digunakan oleh guru belum sesuai dengan tuntutan standar proses. Pembelajaran yang dilakukan dengan memberikan penugasan secara berkelompok untuk membuat makalah belum mampu menghasilkan siswa yang kreatif dan inovatif. Hal ini ditunjukkan dengan makalah yang dihasilkan siswa yang lebih banyak copy paste dari internet, yang salah satunya dibuktikan adanya sebuah ayat yang terbalik-balik karena copy paste dari internet tanpa ditelaah dahulu benar salahnya. Metode pembelajaran ini masih jauh dari tuntutan standar proses, yang mengharapkan siswa menghasilkan karya berbasis pemecahan masalah/project based learning.

Pada kegiatan penutup sebagian sudah sesuai dengan standar proses. Misalnya saja guru memberikan umpan balik terhadap proses pembelajaran yang yang baru saja dilaksanakan. Selain itu, guru juga menginformasikan kepada siswa rencana kegiatan pada pertemuan yang akan datang, dan memberi tugas untuk pertemuan selanjutnya. Namun, kegiatan-kegiatan tersebut juga tidak selalu ada pada rangkaian kegiatan penutup.

Pengataman kedua pada materi yang sama dilakukan pada kelas X MIPA 1 yang diampu oleh Ibu Sri Handayani. Pengamatan pada kelas ini dilakukan pada tanggal 24 Oktober 2015 jam pelajaran ke 1, 2, dan 3. Pada jam pelajaran pertama siswa diberi kesempatan untuk melaksanakan solat Dhuha sebelum pembelajaran dimulai.

Pada kegiatan pendahuluan, guru mengecek daftar presensi siswa, yang dilanjutkan dengan menayangkan hasil UTS melalui layar LCD. Guru juga menyampaikan tujuan pembelajaran dan KD yang akan dicapai melalui slide, dan meminta siswa untuk membaca sendiri. Untuk kegiatan pendahuluan, sebagian besar sudah sesuai dengan standar proses yang tertera dalam Permendikbud Nomor 65 Tahun 2013.

Pada kegiatan inti, guru meminta siswa untuk mengamati buku teks pegangan siswa dan membaca materi tersebut. Pada proses mengamati ini guru juga memotivasi siswa untuk melakukan diskusi dan tanya jawab terkait 
Kami berharap penerbitan prosiding ini dapat memberikan kontribusi bagi pengembangan khazanah sosial keagamaan serta sebagai bahan masukan bagi para pengambil kebijakan tentang pelbagai perkembangan dan dinamika sosial keagamaan di Indonesia. Selain itu, diharapkan pula sebagai acuan sehingga dapat dijadikan sebagai rujukan bagi semua pihak tentang informasi kehidupan keagamaan. Semoga penerbitan prosiding ini dapat memberikan wawasan pengetahuan bagi masyarakat luas, terutama berkaitan dengan data dan informasi penelitian.

Tentu, penerbitan prosiding ini masih banyak kekurangan dan kelemahan, baik tampilan ataupun pilihan kata-kata. Bahkan, dalam penerbitan buku ini masih ada hal-hal yang perlu perbaikan, baik berkaitan dengan sisi subtansi maupun teknis. Oleh karena itu, kami mengharap atas kritik dan sarannya untuk perbaikan dan penyempurnaan penerbitan selanjutnya.

Semarang, November 2016

Kepala

Balai Litbang Agama Semarang

Prof. (R) DR. H. Koeswinarno, M. Hum

NIP : 196312011989031002 
kognitif yang potensial dalam merangsang perkembangan intelek, khususnya keterampilan berpikir tingkat tinggi siswa, dan Keempat dapat mengembangkan karakter siswa (Slamet, 2015: 5). Keempat karakter pendekatan saintifik ini jika benar-benar diterapkan dalam proses pembelajaran akan memotivasi siswa dan guru untuk melakukan proses pembelajaran berbasis kreativitas, bukan sekedar pembelajaran berbasis kecerdasan.

Pelaksanaan Kurikulum 2013 secara teknis telah diatur dalam beberapa dokumen standar. Ketersediaan dokumen-dokumen yang diacu dalam penerapan Kurikulum 2013 menjadi sesuatu yang mutlak bagi seluruh komponen pendidikan yang terkait, terlebih lagi bagi guru. Pemahaman guru terhadap dokumen standar menjadi sangat penting mengingat guru merupakan pelaku utama dalam pembelajaran sebagai salah satu penentu keberhasilan penerapan Kurikulum 2013. Minimal ada tiga standar yang harus dikuasai dan dipahami oleh guru dalam menerapkan Kurikulum 2013, yaitu standar isi, standar proses, dan standar penilaian.

Standar isi yang diacu dalam penerapan Kurikulum 2013 terdapat pada Permendikbud Nomor 64 Tahun 2013, yaitu tentang standar isi pendidikan dasar dan menengah. Standar isi dalam Permendikbud ini mencakup materi minimal dan tingkat kompetensi minimal untuk mencapai kompetensi lulusan minimal pada jenjang dan jenis pendidikan tertentu. Standar isi juga memuat tingkat kompetensi dan ruang lingkup materi sesuai dengan jenjang dan pendidikan tertentu. Pada mapel PAI dan Budi Pekerti, ruang lingkup materi mencakup Al-Quran, Aqidah, Akhlak dan Budi Pekerti, Fiqih, dan Sejarah Peradaban Islam. Ruang lingkup materi disesuaikan dengan kompetensi yang akan dicapai dalam pembelajaran, serta disesuaikan dengan jenjang kelas pada jenjang pendidikan tertentu.

Sebagaimana standar isi, standar proses yang diacu dalam penerapan Kurikulum 2013 juga telah disahkan melalui Permendikbud Nomor 65 Tahun 2015 tentang Standar Proses Pendidikan Dasar dan Menengah. Cakupan standar proses lebih banyak dan lebih bersifat teknis dibanding dengan cakupan standar isi. Permendikbud tentang standar proses ini mencakup pendahuluan, karakteristik pembelajaran, perencanaan pembelajaran, pelaksanaan pembelajaran, penilaian hasil dan proses pembelajaran, dan pengawasan proses pembelajaran.

Standar penilaian yang diacu dalam menerapkan penilaian pembelajaran pada Kurikulum 2013 tertuang dalam Permendikbud Nomor 66 Tahun 2013. Penilaian hasil belajar siswa didasarkan pada prinsip-prinsip objektif, terpadu, ekonomis, transparan, akuntabel, dan edukatif. Penilaian hasil belajar mencakup kompetensi sikap, pengetahuan, dan keterampilan yang dilakukan secara berimbang.

Penilaian ranah sikap dapat dilakukan melalui observasi, penilaian diri, penilaian antar teman, dan jurnal guru. Instrumen yang digunakan untuk jenis penilaian ini adalah daftar cek atau skala penilaian (rating scale) yang disertai rubrik, sedangkan pada jurnal berupa catatan pendidik. Penilaian kompetensi pengetahuan dilakukan melalui tes tulis, tes lisan, dan penugasan. Instrumen tes tulis berupa soal pilihan ganda, isian, jawaban singkat, benar-salah, menjodohkan, dan uraian, yang semuanya dilengkapi dengan pedoman penskoran. Penilaian kompetensi keterampilan dilakukan melalui penilaian kinerja, dengan menggunakan tes praktik, projek, dan penilaian portofolio. Instrumen yang digunakan berupa daftar cek atau skala penilaian (rating scale) yang dilengkapi rubrik.

Untuk melakukan evaluasi terhadap pelaksanaan Kurikulum 2013 pada mata pelajaran PAI di SMA perlu dipahami terlebih dahulu konsep dan prosedur evaluasi itu sendiri. Evaluasi merupakan serapan yang berasal dari bahasa Inggris "evaluation". Evaluasi adalah kegiatan untuk mengumpulkan informasi tentang bekerjanya sesuatu, yang selanjutnya informasi tersebut digunakan untuk menentukan alternatif yang tepat dalam mengambil sebuah keputusan (Arikunto, 2010:2). Menurut Widoyoko (2012;6) evaluasi merupakan proses yang sistematis dan berkelanjutan untuk mengumpulkan, mendeskripsikan, menginterpretasikan, dan menyajikan informasi tentang suatu 
Tabel 1. Komponen dan Subjek Evaluasi

\begin{tabular}{llll}
\hline Komponen & Rincian & Subjek & Alat \\
\hline \multirow{3}{*}{ Context } & $\begin{array}{l}\text { Pendekatan Saintifik dan Kom- } \\
\text { petensi Dasar }\end{array}$ & Guru dan siswa & Observasi \\
\cline { 2 - 4 } & Ketersediaan dokumen standar & Dinas, Kasek, Guru & Instrumen wawancara \\
\cline { 2 - 4 } & Sosialisasi dokumen standar & Dinas, Kasek, Guru & Instrumen wawancara \\
\cline { 2 - 4 } & Dukungan Instansi Terkait & $\begin{array}{l}\text { Dinas, Kemenag, } \\
\text { Kasek }\end{array}$ & Instrumen wawancara \\
\cline { 2 - 4 } Process & Standar Isi & Guru, siswa & Observasi, Instrumen \\
\cline { 2 - 4 } & Standar Proses & Guru, siswa & Observasi, Instrumen \\
\cline { 2 - 4 } Product & Penilaian proses (otentik) & Guru & Observasi, ceklis \\
& Standar Penilaian & & \\
\hline
\end{tabular}

Analisis data dilakukan mulai dari persiapan, pengumpulan data di lapangan, dan setelah selesai pengumpulan data di lapangan. Analisis data pada tahap persiapan dilakukan dengan membuat rumusan masalah yang tepat dan aktual terkait dengan evaluasi Kurikulum 2013. Perumusan masalah penelitian yang tepat akan berimplikasi pada keberfungsian hasil penelitian, yakni rekomendasi dalam menentukan arah kebijakan pemerintah, oleh Kementerian Agama dalam menentukan kebijakan tentang pelaksanaan PAI di SMA yang berpedoman pada Kurikulum 2013.

Analisis data pada tahap pengumpulan data di lapangan dilakukan untuk memperoleh potret pelaksanaan Kurikulum 2013 di SMAN 1 Godean. Analisis dilakukan terhadap data-data tentang pelaksanaan proses pembelajaran PAI, baik dari aspek konteks, input, proses, dan hasil. Selain itu, analisis juga dilakukan terhadap dukungan kepala sekolah, fasilitas pembelajaran, dan juga kondisi siswa. Aktivitas yang dilakukan pada analisis data mengacu pada teori Miles dan Huberman sebagaimana dikutip oleh Rachman (2011: 174), yang meliputi kegiatan data reduction, data display, dan verification.

\section{HASIL PENELITIAN DAN PEMBAHASAN}

\section{Setting Penelitian}

Kabupaten Sleman dengan luas wilayah mencapai 18,04\% dari luas wilayah DIY (BPS, 2015: 7) memiliki lembaga pendidikan sebanyak 1.294 buah, mulai dari jenjang TK hingga SMA (BPS, 2014: 113). Jumlah tersebut menempati urutan kedua terbanyak setelah Kabupaten Gunung Kidul. Pada jenjang pendidikan menengah, jumlah SMA yang bernaung di bawah Dinas Pendidikan sebanyak 42 sekolah, yang terdiri dari SMA negeri 16 unit dan SMA swasta 26 unit. Namun demikian, data SMA yang diperoleh dari Disdikpora Kabupaten Sleman, ada peningkatan jumlah SMA dengan berdirinya beberapa SMA baru, sehingga saat ini mencapai 50 sekolah, terdiri dari SMA negeri 17 sekolah dan SMA swasta 30 sekolah (Kasi Kuriukulum Pendidikan SMA/K Disdikpora Kabupaten Sleman, wawancara 26 Oktober 2015).

Seiring perkembangan kurikulum pendidikan, dari Kurikulum 2006 menjadi Kurikulum 2013, pemerintah Kabupaten Sleman melalui Disdikpora menindaklanjuti dengan menerapkan Kurikulum 2013 pada sekolah yang ditunjuk sebagai pilot project. Setelah setahun berjalan, pelaksanaan Kurikulum 2013 oleh seluruh sekolah yang bernaung di bawah Kemendikbud, mengikuti instruksi pemerintah pusat, pada akhirnya kurikulum dikembalikan kepada Kurikulum 2006 kecuali pada sekolah-sekolah yang ditunjuk. 
Sumber belajar yang digunakan adalah buku teks siswa dan guru. Saat ini buku teks PAI bagi siswa sebagian besar sudah memenuhi 1:1, namun untuk kelas XII kondisi seperti itu belum terpenuhi. Sumber belajar lain adalah LKS, buku-buku yang ada di perpustakaan, sumber dari internet yang relevan dengan materi. Media pembelajaran yang digunakan adalah LCD dan screen, HP dan laptop dalam mendukung metode info search dalam diskusi, internet, dan alat peraga.

Dokumen penilaian pembelajaran berbasis penilaian otentik dalam beberapa RPP sudah terlampir. Diantaranya adalah penilaian sikap (dalam diskusi), penilaian psikomotorik (kemampuan presentasi). Namun belum ada satupun instrumen penilaian yang mengamati kegiatan belajar siswa yang mencakup 5M.

\section{Evaluasi Proses Pembelajaran PAI dan Budi Pekerti}

\section{Evaluasi Konteks Pembelajaran}

Konteks yang dimaksud dalam penelitian evaluasi ini adalah materi, KD, dan metode saintifik yang diterapkan dalam pembelajaran. Penelitian ini tidak mengevaluasi seluruh KD yang ada, namun hanya beberapa KD yang disampaikan di kelas X, XI, dan XII. Evaluasi dilakukan dengan mempelajari dokumen dan proses pembelajaran pada beberapa KD pada lima materi pokok, yaitu:

\section{a. Al-Quran Hadits Pedoman Hidupku}

Materi ini disampaikan pada kelas X dengan alokasi waktu 4 × 3 JP. Kompetensi dasar yang harus tuntas selama 4 kali pertemuan ini sebanyak $3 \mathrm{KD}$, yang masing-masing merupakan implementasi dari KI-1, KI-3, dan KI-4. Ketiga KD tersebut mengacu pada Permendikbud Nomor 59 Tahun 2014, yaitu berpegang teguh pada Al-Quran, Hadits, dan Ijtihad sebagai pedoman hidup (KD 1.2), memahami kedudukan Al-Quran, Hadits, dan Ijtihad sebagai sumber hukum Islam (KD.3.8), dan menyajikan macam-macam sumber hukum Islam (KD 4.6). Penyajian KD pada RPP yang disusun oleh guru sudah sesuai dengan Permendikbud Nomor 59 Tahun 2014.

Pendekatan saintifik dalam pencapaian KD dilakukan dengan menerapkan tiga strategi pembelajaran yang berbeda pada setiap pertemuan. Pertemuan pertama pendekatan saintifik dilakukan melalui strategi pembelajaran Student Created Case Studies. Pertemuan kedua menggunakan strategi pembelajaran Reading Guide, dan pertemuan ketiga menggunakan strategi pembelajaran Everyone is Teacher here. Ketiga metode pembelajaran tersebut merupakan strategi pembelajaran koperatif, apabila diterapkan dengan baik dan benar akan selaras dengan tujuan pembelajaran saintifik.

\section{b. Pelaksanaan Tata Cara Penyelenggaraan Jenazah}

Materi Pelaksanaan Tata Cara Penyelenggaraan Jenazah diberikan pada siswa kelas XI dengan alokasi waktu 2 x 3 JP. KD yang akan dicapai dalam materi pembelajaran ini adalah menerapkan ketentuan syariat Islam dalam penyelenggaraan jenazah (KD 1.4), memahami pelaksanaan tatacara penyelenggaraan jenazah (KD 3.9), dan memperagakan tatacara penyelenggaraan jenazah (KD 4.9). Penyajian ketiga KD tersebut dalam RPP belum seluruhnya sesuai dengan Permendikbud Nomor 59 Tahun 2014. Hal ini dapat dilihat pada RPP yang guru susun masih tercantum KD 4.11 untuk memperagakan tatacara penyelenggaraan jenazah. Hal ini menunjukkan bahwa guru masih mengacu pada Permendikbud Nomor 69 Tahun 2013, karena pada Permendikbud Nomor 59 Tahun 2014 memperagakan tatacara penyelenggaraan jenazah merupakan KD 4.9. 


\section{Prosiding: Evaluasi Kurikulum 2013 Mata Pelajaran Pendidikan Agama Islam Pada SMA di Jawa Tengah Dan D.I.Yogyakarta}

materi yang telah diamati tersebut. Dalam kegiatan mengamati dan menanya ini, guru lebih memberikan kesempatan kepada siswa untuk bertanya dan menjawab, dimana guru hanya bersifat mendukung jalannya diskusi tanya jawab.

Masih pada kegiatan inti, untuk mengkondisikan siswa melakukan eksplore, guru membagi siswa menjadi enam kelompok, dengan teknik pembagian kelompok dengan cara berhitung. Masing-masing kelompok bertugas mengerjakan soal yang disediakan oleh guru, dimana setiap kelompok mendapat soal yang sama. Kegiatan eksplore dan asosiasi berjalan pada saat diskusi kelompok. Selanjutnya proses mengkomunikasikan dilakukan dengan presentasi kelompok yang dilakukan oleh seluruh anggota kelompok (tidak diwakilkan). Pelaksanaan kegiatan inti pembelajaran yang dilakukan oleh guru PAI sudah sesuai dengan skenario pembelajaran di RPP. Namun karena soal yang diberikan sama, maka materi-materi yang bersifat normatif menghasilkan karya yang sama antar kelompok diskusi. Sisi yang sedikit berbeda adalah tentang dalil-dalil yang digunakan sebagai dasar pelaksanaan solat fardlu, cara berpakaian, dan sikap toleransi terhadap perbedaan penentuan awal bulan ramadhan.

Metode pembelajaran yang digunakan guru, meski sudah sesuai dengan skenario dalam RPP, namun belum sesuai dengan tuntutan standar proses. Siswa mengerjakan tugas kelompok dengan mengacu pada referensi internet yang ditulis kembali dalam lembar tugas, tanpa dilakukan asosiasi dan telaah. Hal ini menunjukkan bahwa pembelajaran dengan metode yang digunakan belum mampu menghasilkan karya yang berbasis pemecahan masalah. Hal ini juga ditunjukkan pada saat presentasi, ada siswa yang bertanya, presenter merasa kesulitan untuk menjawabnya.

Kegiatan penutup yang dilakukan guru sebagian besar sudah sesuai dengan standar proses. Namun, guru acap kali tidak memberikan tindak lanjut dalam bentuk pemberian tugas, baik tugas individual maupun kelompok.

\section{b. Pelaksanaan Tata Cara Penyelenggaraan Jenazah}

Evaluasi terhadap pelaksanaan pembelajaran dilakukan dengan melakukan pengamatan langsung pada tanggal 22 Oktober 2015, dengan kelas pengamatan adalah kelas XI IPS 1 pada jam pelajaran ke 6, 7, dan 8, yang diampu oleh Pak Suparyanta. Pembelajaran yang diamati merupakan pertemuan ke-2 dari KD 3.9, dimana pertemuan sebelumnya siswa diberi tugas untuk membuat bahan presentasi dan menayangkan video tentang penyelenggaraan jenazah. Pada pertemuan ke-2 ini siswa secara berkelompok melakukan presentasi tentang hasil kerja kelompoknya masing-masing.

Kegiatan mengamati dilakukan siswa dengan mengamati substansi slide dan video yang ditayangkan oleh kelompok presenter. Dalam kegiatan presentasi ini, siswa juga melakukan aktivitas menanya yang ditujukan kepada kelompok presenter. Kelompok presenter melakukan analisis terhadap materi dan pertanyaan siswa sehingga mampu menjawab apa yang ditanyakan siswa. Selain itu, kegiatan mengkomunikasikan juga terlihat pada saat presentasi, dimana kelompok presenter mengkomunikasikan hasil kerja mereka melalui presentasi dan diskusi selama presentasi berlangsung.

Kegiatan mencoba dilakukan dengan memberikan kesempatan kepada siswa untuk melaksanakan praktik atau demonstrasi tentang tatacara penyelenggaraan jenazah, yang dilakukan di musola dengan alat peraga yang sudah disediakan. Kegiatan praktik dimulai dari materi tentang cara menghadapi orang yang sakaratul maut, memandikan jenazah, mengkafani, mensolati, sampai menguburkan jenazah. Siswa dibagi menjadi beberapa kelompok, dimana kelompok pengamat diberi kesempatan untuk mengamati, menanya, dan menanggapi praktik yang dilakukan oleh kelompok lain. 
Pelaksanaan pembelajaran yang dilakukan oleh Pak Suparyanto sebagian besar sudah sesuai dengan skenario dalam RPP. Kelima sintaks pendekatan saintifik juga sudah dilakukan dalam pembelajaran baik di kelas maupun di musola pada saat praktik. Hanya saja skenario pada RPP tertulis bahwa kegiatan mencoba dilakukan dengan diskusi kelompok, sedang pada kenyataannya kegiatan ini dilakukan melalui praktik pengurusan jenazah oleh siswa secara berkelompok.

Jika dikaitkan dengan standar proses, pelaksanaan pembelajaran yang diampu oleh Pak Suparyanta belum sepenuhnya sesuai dengan standar proses. Dalam kegiatan pendahuluan, guru tidak menyiapkan peserta didik secara psikis dan fisik, tidak memberi motivasi, dan tidak menjelaskan kompetensi dasar yang akan dicapai.

Pada kegiatan inti, guru tidak lagi menggunakan metode ceramah dalam penyampaian materi pembelajaran. Guru hanya memfasilitasi kegiatan diskusi melalui presentasi kelompok terkait tugas yang telah diberikan pada minggu sebelumnya. Guru juga memberikan tugas praktik secara berkelompok, dengan didampingi oleh guru. Dalam pembelajaran kali ini, Guru sudah melakukan proses pembelajaran sesuai dengan standar proses pembelajaran. Selain pembelajaran yang terjadi berpusat pada siswa, melalui pembelajaran ini guru juga menanamkan sikap sosial berupa peduli sosial, dengan memberikan motivasi kepada siswa untuk berpartisipasi di masyarakat manakala ada anggota masyarakat yang meninggal dunia.

Kegiatan penutup yang dilakukan guru belum sepenuhnya sesuai dengan standar proses pembelajaran. Pada kegiatan ini guru tidak memberikan tindak lanjut berupa penugasan/tes secara individu maupun kelompok. Namun demikian, secara umum kegiatan penutup sudah dilakukan guru dengan mengacu pada standar proses pembelajaran.

\section{c. Khutbah, Tabligh, dan Dakwah}

Evaluasi terhadap pelaksanaan proses pembelajaran dilakukan melalui pengamatan pembelajaran di kelas XI MIPA 4 pada tanggal 27 Oktober 2015. Kelas amatan diampu oleh Ibu Sri Handayani pada jam pelajaran ke 1, 2, dan 3. Pengamatan kelas pada kesempatan ini merupakan pertemuan ke-1 dari KD 3.10. Satu jam pertama digunakan untuk melaksanakan salat dhuha secara bergantian, dilanjutkan dengan hafalan ayat-ayat Al-Quran yang merupakan bagian dari materi pembelajaran kelas XI. Hal ini merupakan strategi guru atas kesulitan siswa membaca dan menghafal ayat-ayat $\mathrm{Al}$-Quran.

Kegiatan pendahuluan dilakukan dengan mengecek kehadiran siswa melalui daftar presensi siswa. Guru juga menayangkan tujuan pembelajaran dan kompetensi dasar yang akan dicapai, dengan meminta siswa untuk membacanya. Namun, guru tidak memberi penjelasan kepada siswa tentang tujuan pembelajaran dan kompetensi dasar yang akan dicapai. Kegiatan pendahuluan yang tidak dilakukan guru misalnya memberikan motivasi belajar siswa secara kontekstual. Dengan demikian, kegiatan pendahuluan yang dilakukan guru belum sepenuhnya sesuai dengan standar proses.

Kegiatan inti pada KD ini dilakukan sesuai dengan skenario dalam RPP, yaitu menggunakan strategi synergetic teaching. Guru membagi kelas menjadi dua bagian, yaitu kelompok bernomor absen genap dan ganjil. Kelompok ganjil diberi tugas melakukan pengamatan terhadap materi khutbah, tabligh, dan dakwah di perpustakaan, dengan memanfaatkan sumber belajar dan media yang ada di perpustakaan. Hasil pengamatan ditulis oleh seluruh anggota kelompok ganjil. Kelompok genap memperoleh materi dari guru di kelas. Kegiatan ini berlangsung selama 25 menit, hingga kelompok ganjil kembali ke kelas. Guru membagi kelas menjadi empat kelompok, yang masing-masing kelompok terdapat siswa bernomor ganjil dan genap. Tugas masing-masing kelompok adalah melaku- 


\section{Prosiding: Evaluasi Kurikulum 2013 Mata Pelajaran Pendidikan Agama Islam Pada SMA di Jawa Tengah Dan D.I.Yogyakarta}

kan eksplore dan mengasosiasi apa yang telah diperoleh, baik dari perpustakaan maupun dari guru. Selanjutnya masing-masing kelompok melakukan presentasi di depan kelas, sedang guru memfasilitasi kegiatan tanya jawab di kelas.

Kegiatan inti yang telah dilakukan guru sudah mencakup lima sintaks dalam pendekatan saintifik. Namun, metode pembelajaran yang digunakan ternyata tidak mampu membawa siswa ke sebuah karya yang berbasis pemecahan masalah. Hal ini terlihat dari apa yang dipresentasikan siswa lebih bersifat tekstual, berdasarkan materi dalam buku teks dan sumber dari internet, sehingga substansi dari masing-masing kelompok hampir seluruhnya sama, tidak ada unsur kreativitas dan inovasi. Dengan demikian, pembelajaran berbasis pemecahan masalah sebagai tujuan pendekatan saintifik sebagaimana tercantum dalam standar proses belum tercapai.

Kegiatan penutup yang dilakukan oleh guru tidak seluruhnya sesuai dengan standar proses. Guru melakukan refleksi dengan membuat rangkuman yang melibatkan siswa. Guru juga memberikan informasi rencana kegiatan pembelajaran pada pertemuan berikutnya. Guru tidak melakukan tindak lanjut dalam bentuk pemberian tugas, baik individu maupun kelompok. Dengan demikian, kegiatan penutup yang dilakukan guru belum sepenuhnya sesuai dengan standar proses.

\section{d. Memahami Hukum Islam tentang Hukum Keluarga}

Evaluasi pelaksanaan pembelajaran dilakukan dengan melakukan pengamatan pembelajaran pada kelas XII IPS 2 yang diampu oleh Bapak Suparyanta. Pengamatan dilakukan pada tanggal 23 Oktober 2015 pada jam pelajaran ke 4, 5, dan 6. Pembelajaran yang diamati merupakan pertemuan ke-2, di mana pertemuan sebelumnya siswa diberi tugas untuk membuat bahan presentasi tentang pernikahan disertai dengan video pernikahan.

Kegiatan pendahuluan yang ada pada standar proses tidak seluruhnya dilakukan oleh guru. Penyiapan peserta didik secara psikis dan fisik serta memberi motivasi kepada siswa belum sepenuhnya dilakukan. Demikian juga tujuan pembelajaran dan kompetensi dasar yang akan dicapai tidak disampaikan kepada siswa.

Kegiatan inti pada pertemuan kedua ini diawali dengan presentasi kelompok terkait penugasan yang telah diberikan pada pertemuan sebelumnya. Substansi presentasi tidak sesuai dengan skenario pembelajaran dalam RPP, dimana dalam skenario pertemuan kedua digunakan untuk membahas tentang hak dan kedudukan wanita dalam keluarga berdasarkan hukum Islam. Praktiknya, substansi pembelajaran kembali lagi pada ranah tentang pernikahan, yang ditayangkan oleh siswa melalui slide dan video. Materi kedudukan wanita dalam keluarga juga dipresentasikan siswa yang menjadi voluntir untuk maju ke depan.

Pada kegiatan inti, siswa melakukan kegiatan mengamati melalui tayangan video dan slide yang dipresentasikan oleh kelompok lain. Selama presentasi kelompok, siswa juga melakukan kegiatan menanya, yang dijawab juga oleh siswa lain. Selain itu, kegiatan mengkomunikasikan juga terpenuhi melalui presentasi hasil kerja kelompok. Dalam kegiatan ini, guru hanya mendampingi dan memfasilitasi kegiatan diskusi selama presentasi berlangsung. Melalui penayangan video, siswa juga melakukan melakukan eksplore dan asosiasi, misalnya saja dengan menginventarisir unsur-unsur yang ada dalam pernikahan melalui video yang ditayangkan.

Kegiatan eksplore diperkuat lagi dengan demontrasi tata cara pernikahan oleh siswa secara berkelompok. Dalam kegiatan demonstrasi ini, siswa juga melakukan kegiatan-kegiatan pembelajaran dengan pendekatan saintifik. Namun, karena keterbatasan pengetahuan siswa tentang tata cara menjadi penghulu, pada kegiatan demonstrasi yang berperan sebagai penghulu adalah guru. Hal ini menyebabkan siswa kurang maksimal dalam melakukan eksplore dan mencapai KD yang diharapkan. Kegiatan inti yang berjalan secara umum sudah sesuai dengan standar 
proses dan tuntutan Kurikulum 2013. Hal ini terlihat dengan adanya dominasi siswa dalam pembelajaran, meski belum secara maksimal tercapai.

Kegiatan penutup yang dilakukan guru secara umum sudah sesuai dengan standar proses. Hal ini ditunjukkan dengan guru melakukan umpan balik, memberi penugasan secara berkelompok, dan memberi informasi rencana kegiatan pembelajaran pada pertemuan berikutnya.

e. Rahmat Islam di Nusantara

Evaluasi pelaksanaan proses pembelajaran pada materi ini dilakukan melalui pengamatan kelas XII MIPA 1 pada tanggal 30 Oktober 2015 jam pelajaran ke 4, 5, dan 6. Pembelajaran yang diampu oleh Ibu Sri Handayani ini merupakan pertemuan kedua untuk materi "Rahmat Islam di Nusantara" ini. Pembelajaran diawali dengan berdoa bersama dalam hati dengan menundukkan kepala.

Kegiatan pendahuluan dilakukan guru dengan mengecek kehadiran siswa dan menghafal ayat-ayat Al-Quran yang menjadi bagian dari materi PAI kelas XII selama setahun. Guru juga menyampaikan KD dan tujuan pembelajaran melalui slide yang dibaca oleh siswa, tanpa ada penjelasan yang disampaikan oleh guru.

Kegiatan inti diawali dengan kegiatan mengamati, dimana siswa disuruh untuk membaca materi yang ada di buku teks siswa selama 15 menit. Setelah itu, guru memfasilitasi siswa untuk menanya apa saja yang mereka peroleh dari kegiatan mengamati. Guru juga memotivasi siswa untuk menjawab pertanyaan yang dilontarkan oleh siswa yang lain.

Kegiatan eksplore dilakukan dengan strategi pembelajaran Gallery Walk. Siswa dibagi menjadi empat kelompok. Tugas masing-masing kelompok membuat resume dengan tema yang berbeda, yaitu (1) strategi dakwah Islam di nusantara, (2) masuknya Islam di Nusantara, (3) faktor apa saja yang menyebabkan penyebaran Islam berkembang di Nusantara, dan (4) cara penyebaran Islam di Nusantara. Siswa menggunakan beberapa macam sumber dan media belajar yang tersedia, misalnya saja buku teks siswa, bahan dari internet, laptop, dan hp. Dalam kegiatan diskusi kelompok ini, siswa juga melakukan asosiasi terhadap beberapa informasi yang diperoleh dari sumber-sumber yang berbeda.

Kegiatan selanjutnya, masing-masing kelompok menunjuk satu orang juru bicara dan satu orang asistennya untuk mengkomunikasikan hasil kerja kelompok. Hasil kerja kelompok di tempel di dinding dan siap untuk dipresentasikan kepada pengunjung. Siswa yang tidak bertugas sebagai jubir berkunjung ke kelompok lain, dimana dalam kegiatan ini terjadi proses mengamati, menanya, mengeksplore, mengasosiasi, dan juga mengkomunikasikan. Pengunjung mendatangi kelompok-kelompok lain untuk menyerap informasi yang berbeda. Guru dalam hal ini berperan sebagai pembimbing dan penilai aktivitas pembelajaran siswa.

Kegiatan penutup dilakukan guru dengan memberikan umpan balik kepada siswa terkait pembelajaran yang sudah berlangsung, dan membuat rangkuman dengan melibatkan siswa. Guru mengumpulkan seluruh hasil kerja siswa, serta menginformasikan tindak lanjut dengan memberikan arahan kegiatan pada pertemuan selanjutnya.

Dari paparan hasil pengamatan kelas, guru sudah melakukan pembelajaran sesuai dengan skenario pembelajaran dalam RPP. Guru tidak melakukan metode ceramah sama sekali, sehingga dalam RPP semestinya sudah tidak tercantum metode ceramah. Strategi pembelajaran yang digunakan juga sudah sesuai dengan standar proses, dimana pembelajaran yang berlangsung sudah melibatkan siswa secara aktif dan berpusat pada siswa.

Evaluasi proses yang dihasilkan melalui telaah dokumen RPP dan pengamatan kelas pada lima materi pokok menunjukkan bahwa dokumen RPP yang disusun guru belum sesuai dengan standar isi dan standar proses. Hal ini 
untuk instrumen tes essay. Selain itu, guru juga belum mencantumkan kunci jawaban untuk tes pilihan ganda sebagaimana yang seharusnya ada pada dokumen RPP.

Selain itu, guru PAI belum memahami secara maksimal pedoman penilaian yang seharusnya diacu dalam pelaksanaan Kurikulum 2013. Pada RPP yang ditelaah belum satu pun yang mencantumkan instrumen penilaian otentik yang berupa instrumen pengamatan guru pada lima sintak/kegiatan belajar, yaitu mengamati, menanya, mencoba, mengasosiasi, dan mengkomunikasikan. Selain itu, instrumen penilaian yang disusun dalam RPP belum secara keseluruhan mencakup kompetensi sikap spiritual, sikap sosial, pengetahuan, dan keterampilan. Dengan kata lain, penilaian yang disusun oleh guru yang menyatu dalam dokumen RPP belum sesuai dengan Permendikbud Nomor 66 Tahun 2013 dan Permendikbud Nomor 104 Tahun 2014 tentang Penilaian Hasil Belajar oleh Pendidik pada Pendidikan Dasar dan Pendidikan Menengah.

Dalam proses pembelajaran, tidak seluruh instrumen penilaian dalam RPP digunakan oleh guru. Bahkan dapat dikatakan bahwa seluruh instrumen penilaian sikap dan psikomotorik (instrumen non tes) tidak digunakan dalam proses pembelajaran. Untuk melakukan penilaian sikap siswa dalam berdiskusi misalnya, guru hanya memberikan tanda atau penilaian pada lembar presensi siswa. Guru PAI yang lain melakukan penilaian sikap tanpa menggunakan instrumen penilaian sama sekali. Kondisi seperti ini diakui oleh guru PAI karena banyaknya dokumen yang harus disusun oleh guru di luar dokumen penilaian, sehingga guru tidak memiliki waktu untuk menyusun instrumen penilaian sikap dan psikomotorik. Selain itu, mereka juga mengakui bahwa standar penilaian otentik yang diterapkan dalam Kurikulum 2013 sangat rumit dan sulit untuk diterapkan dalam proses pembelajaran. Hal ini juga diakui oleh kepala sekolah bahwa dalam penerapan Kurikulum 2013 yang paling sulit dilakukan adalah penilaian oleh guru.

Dari beberapa instrumen penilaian yang disusun dalam RPP, meski sebagian besar tidak diterapkan dalam penilaian pembelajaran, guru PAI pernah menerapkan penilaian sikap melalui teknik penilaian diri. Namun sayangnya hal ini tidak rutin dilaksanakan, yang semestinya jika mengacu pada standar penilaian, penilaian diri dilakukan setiap kali sebelum ulangan harian.

\section{Faktor Pendukung dan Penghambat}

Pelaksanaan Kurikulum 2013 tidak terlepas dari faktor pendukung dan penghambat yang menyertainya. Pada SMAN 1 Godean, pelaksanaan Kurikulum 2013 dapat berjalan cukup baik karena didukung oleh sarana dan prasarana yang memadai, misalnya saja adanya LCD projector di masing-masing kelas, dan alat peraga untuk praktikum.

Kultur guru yang dinamis turut serta menjadi faktor pendukung terlaksananya Kurikulum 2013 di SMAN 1 Godean. Dari sejumlah guru yang mengajar di sekolah ini, terdapat kurang lebih enam orang guru yang sudah menyandang status sebagai instruktur nasional, yang semuanya merupakan guru mapel umum. Selain itu, 98\% guru memiliki antusiasme yang cukup tinggi terhadap proses pembelajaran yang menggunakan pendekatan saintifik dalam Kurikulum 2013 (Kepala SMAN 1 Godean, wawancara 26 Oktober 2015). Kultur guru yang dinamis tentunya akan membawa dampak positif bagi guru PAI sebagai bagian dari keluarga besar SMAN 1 Godean. Dukungan yang diperoleh dari guru mapel lain memberikan motivasi tersendiri bagi peningkatan kualitas guru PAI, khususnya dalam menerapkan pembelajaran saintifik sesuai dengan tuntutan Kurikulum 2013. Hal ini terlihat dari proses pembelajaran PAI yang sudah menerapkan pembelajaran yang bervariatif, yang mengacu pada proses pembelajaran dengan partisipasi aktif siswa. 


\section{Prosiding: Evaluasi Kurikulum 2013 Mata Pelajaran Pendidikan Agama Islam Pada SMA di Jawa Tengah Dan D.I.Yogyakarta}

ditunjukkan dengan penulisan kompetensi inti yang masih salah, penulisan KD yang belum seluruhnya mengacu pada Permendikbud Nomor 59 Tahun 2014, metode pembelajaran masih tertulis metode ceramah, dan cakupan materi yang hampir tidak ada.

Evaluasi proses pembelajaran yang diperoleh melalui pengamatan kelas terhadap enam kali proses pembelajaran menunjukkan bahwa kualitas proses pembelajaran PAI belum sepenuhnya sesuai dengan standar proses. Komponen-komponen yang ada pada kegiatan pendahuluan, kegiatan inti, dan kegiatan penutup tidak seluruhnya dilakukan oleh guru. Meski demikan, metode ceramah yang tertulis dalam RPP sudah tidak terlihat dalam kegiatan pembelajaran, yang artinya pembelajaran sudah mengarah pada siswa sebagai pusat pembelajaran.

\section{Evaluasi Produk Pembelajaran}

Penilaian otentik sebagai aspek produk dalam proses pembelajaran masih belum sepenuhnya diterapkan dalam proses pembelajaran. Dengan alasan terlalu banyak administrasi yang harus dibuat, guru hanya melampirkan instrumen dalam RPP tanpa digunakan dalam pembelajaran. Hal ini juga diakui oleh kepala sekolah, bahwa guru masih kesulitan menerapkan penilaian otentik di dalam kelas.

Instrumen penilaian yang disusun menyatu dalam dokumen RPP masih belum sesuai sepenuhnya dengan standar penilaian yang diacu. Penilaian yang mengacu pada standar penilaian mencakup penilaian sikap, pengetahuan, dan keterampilan. Pada beberapa RPP yang disusun oleh guru PAI sudah memuat ketiga ranah penilaian tersebut. Penyusunan instrumen penilaian masih belum sempurna sesuai dengan standar penilaian. Misalnya saja dalam lembar instrumen penilaian diri tidak disertai dengan pedoman penskoran sehingga akan menyulitkan guru dalam melakukan skoring akhir.

Pada instrumen penilaian portofolio masih belum memenuhi standar penilaian yang seharusnya. Misalnya saja pada kolom aspek yang diamati, yang terdiri dari lima item amatan tidak dijelaskan apa saja aspek amatan dalam makalah yang ditugaskan kepada siswa. Pada kolom tersebut hanya tertulis angka 1 sampai dengan 5 tanpa penjelasan. Hal ini akan sangat menyulitkan guru jika instrumen tersebut benar-benar diterapkan dalam proses pembelajaran. Selanjutnya pada keterangan di bawah tabel, tertera aspek yang dinilai mencakup 1 adalah kurang, 2 cukup, 3 sedang, dan 4 baik. Kata 'aspek yang dinilai' mestinya ditulis dengan 'keterangan' atau 'skala penilaian', karena yang tertera di bawah merupakan skor yang akan dibubuhkan pada kolom aspek yang diamati. Selain itu, skor 2 yang berarti cukup dan 3 yang berarti sedang sulit diukur perbedaannya, kecuali jika guru mencantumkan rubrik atau descriptor yang jelas.

Pada rumus perhitungan skor akhir, penggunaan kata 'skor tertinggi' sebagai faktor pembagi kurang tepat. Hal ini karena skor tertinggi lebih berarti skor tertinggi yang berhasil dicapai oleh siswa. Padahal sebagai faktor pembagi yang seharusnya adalah 'skor maksimal', bukan 'skor tertinggi', karena dua kata ini jelas berbeda maknanya. Selain itu pada contoh yang diberikan tidak konsisten dengan pedoman skor yang diberikan, dimana pada pedoman skor tertinggi adalah 4 untuk 'baik', sementara pada contoh tertulis 'sangat baik'. Kesalahan juga terlihat pada perhitungan skor maksimal yang tertulis, sementara angka 25 tidak mungkin dicapai manakala slake penskoran yang digunakan adalah 1 sampai 4. Kesalahan yang dilakukan guru PAI dalam penyusunan instrumen di atas menunjukkan bahwa instrumen penilaian portofilio yang disusun dalam RPP masih kurang baik.

Instrumen penilaian ranah pengetahuan disusun dalam bentuk instrumen tes, yang biasanya memuat lima soal pilihan ganda dan lima soal esay. Pada soal esay, guru terkadang belum tuntas mencantumkan rubrik penskoran. Dari beberapa instrumen terlihat bahwa guru PAI belum menyelesaikan rubrik yang sekaligus kunci jawaban 


\section{Prosiding: Evaluasi Kurikulum 2013 Mata Pelajaran Pendidikan Agama Islam Pada SMA di Jawa Tengah Dan D.I.Yogyakarta}

Pelaksanaan Kurikulum 2013 juga didukung oleh input siswa yang cukup tinggi, sehingga proses pembelajaran yang berpusat pada siswa tidak menjadi kendala berarti. Mereka dengan sangat mudah beradaptasi dengan perubahan kurikulum, ditambah dengan bekal penguasaan IT yang sudah baik. Potensi dan kualitas akademik yang dimiliki siswa ini menjadi modal yang bagus, jika dipadukan dengan kreativitas guru dalam mengajar maka dapat tercapai proses pembelajaran yang diharapkan.

Selain faktor pendukung, beberapa hal yang dianggap sebagai faktor penghambat perlu mendapatkan solusi terbaik. Diantaranya adalah beban mengajar guru PAI yang cukup tinggi sementara usia guru sudah tidak muda lagi. Guru PAI dan Budi Pekerti terdiri dari dua orang, dengan beban jam mengajar masing-masing 27 jam pelajaran per minggu. Rombel yang menjadi tanggung jawab mereka terdiri dari delapan belas rombel, sehingga satu orang guru mengajar pada sembilan rombel, dimana satu rombel memiliki alokasi waktu tiga jam pelajaran per minggu. Banyaknya beban mengajar guru PAI berimplikasi pada padatnya jam mengajar dan banyaknya dokumen yang harus dipenuhi guru, mulai dokumen perencanaan, pembelajaran, sampai dokumen penilaian. Hal ini mengakibatkan guru PAI merasa kesulitan untuk memenuhi seluruh dokumen pembelajaran yang disaratkan dalam pelaksanaan Kurikulum 2013.

Selain beban mengajar yang berlebih, guru dibebani juga dengan tugas-tugas di luar tugasnya sebagai guru PAI. Tugas-tugas tersebut misalnya saja sebagai wali kelas, bendahara pembangunan masjid, dan pendampingan siswa sehingga mengakibatkan beberapa tuntutan administrasi guru tercecer dan tidak terpenuhi. Terlebih lagi untuk melakukan penilaian otentik, guru merasa belum mampu untuk memenuhi standar penilaian di tengah beban yang cukup menyita banyak tenaga, waktu, dan pikiran.

Penguasaan IT belum sepenuhnya dapat dipenuhi oleh guru PAI di SMAN 1 Godean, khususnya salah satu guru yang dapat dibilang sudah senior. Kurangnya pengetahuan dan keterampilan dalam mengoperasionalkan komputer dan mengakses internet menjadi kendala yang cukup berarti dalam memenuhi tuntutan Kurikulum 2013. Hal ini berimplikasi pada kurang cepatnya informasi yang diterima terkait Kurikulum 2013, dan kerjasama dengan partner guru PAI dalam satu sekolah menjadi terkendala.

Faktor penghambat yang paling dominan adalah penguasaan guru PAI terkait pelaksanaan Kurikulum 2013 yang belum optimal. Hal ini disebabkan karena minimnya pelatihan Kurikulum 2013 yang diperoleh guru PAI, khususnya pelatihan-pelatihan yang bersifat teknis dan operasional, mulai dari bagaimana menyusun perencanaan pembelajaran, pelaksanaan pembelajaran, sampai pada proses penilaian yang mengacu pada dokumen standar pelaksanaan Kurikulum 2013.

\section{PENUTUP}

Pelaksanaan Kurikulum 2013 di SMAN 1 Godean jika dilihat dari ketersediaan dokumen standar, kesiapan guru, dan dukungan instansi terkait sudah cukup baik. Hal ini ditunjukkan dengan tersedianya seluruh dokumen standar, baik yang ada di sekolah maupun yang dimiliki oleh guru. Kesiapan guru dalam pelaksanaan Kurikulum 2013 diperoleh melalui kegiatan pelatihan atau sosialisasi yang diselenggarakan oleh Kementerian Agama. Selain itu, penyelenggaraan IHT, meski bersifat umum, turut memberikan kontribusi bagi kesiapan guru PAI dalam pelaksanaan Kurikulum 2013.

Evaluasi pembelajaran PAI di SMAN 1 Godean dilihat dari konteks masih kurang baik. Hal ini terlihat dari ketidaksesuaian beberapa KD dengan Permendikbud Nomor 59 Tahun 2014. Selain itu, metode pembelajaran yang masih menggunakan ceramah pada RPP tidak sesuai dengan standar proses yang mengharuskan pembelajaran 
berpusat pada siswa. Evaluasi dari aspek input sudah cukup baik, yang ditunjukkan dengan keikutsertaan guru PAI pada pelatihan dan sosialisasi Kurikulum 2013. Evaluasi dari aspek proses menunjukkan hasil yang masih kurang baik. Hal ini terlihat dari dokumen RPP dan proses pembelajaran yang belum sesuai dengan standar operasional. Demikian juga evaluasi dari aspek produk juga masih menunjukkan hasil yang kurang baik. Hal ini dapat dilihat dari teknik dan dokumen penilaian yang dilakukan oleh guru PAI belum sesuai dengan standar penilaian.

Pelaksanaan Kurikulum 2013 pada proses pembelajaran PAI di SMAN 1 Godean didukung oleh beberapa faktor, yaitu sarana prasarana yang memadai, kultur guru yang cukup dinamis, dan kualitas input siswa. Sedangkan faktor yang menghambat pelaksanaan proses pembelajaran PAI di sekolah ini adalah beban mengajar guru yang relatif tinggi, perbedaan individual siswa, dan penguasaan IT yang belum memadai dan masih minimnya pelatihan Kurikulum 2013 yang diperoleh oleh guru PAI.

\section{DAFTAR PUSTAKA}

\section{Buku dan Literatur}

Arikunto, S. dan Abdul Jabar, C. Safrudin.2010.Evaluasi Program Pendidikan.Pedoman Teoretis Praktis Bagi Mabasiswa dan Praktisi Pendidikan. Jakarta: Bumi Aksara.

Astuti, Tri Marhaeni Pudji. 2013. Kata Kunci Kurikulum 2013. Disampaikan pada Workshop Implementasi Pendidikan Agama Islam dalam Kurikulum 2013 pada Sekolah Menengah Atas” yang diselenggarakan oleh Balai Litbang Agama Semarang tanggal 11 s.d. 14 November 2013

Atsnan, M.F. dan Rahmita Yuliana Gazali.2013.Penerapan Pendekatan Scientific Dalam Pembelajaran Matematika SMP Kelas VII Materi Bilangan (Pecahan). Prosiding Seminar Nasional Matematika dan Pendidikan Matematika dengan tema " Penguatan Peran Matematika dan Pendidikan Matematika untuk Indonesia yang Lebih Baik" pada tanggal 9 November 2013 di Jurusan Pendidikan Matematika FMIPA UNY.

BPS Provinsi D.I. Yogyakarta.2014. D.I. Yogyakarta Dalam Angka 2014.

Dyers, J.H. et al. 2011. Innovators DNA: Mastering The Five Skills of Disruptive Innovetors. Harvard Business Review.

Rachman, Maman. 2011. Metode Penelitian Pendidikan Moral dalam Pendekatan Kuantitatif, Kualitatif, Campuran, Tindakan, dan Pengembangan. Semarang: Unnes Press

Slamet, Achmad. 2015. Evaluasi Pelaksanaan Kurikulum 2013 Mata Pelajaran Pendidikan Agama. Makalah disampaikan pada kegiatan Pengayan Teori Penelitian Evaluasi Pelaksanaan Kurikulum 2013 Mata Pelajaran Pendidikan Agama diselenggarakan oleh Balai Penelitian dan Pengembangan Agama Semarang tanggal 1 September 2015.

Sudjana, Nana dan Ibrahim. 2004. Penelitian dan Penilaian Pendidikan. Bandung: Sinar Baru Algesindo.

Sujarwanta, Agus. 2012. “Mengkondisikan Pembelajaran IPA dengan Pendekatan Saintifik”. Jurnal Nuansa Kependidikan Vol 16 Nomor1, Nopember 2012. Halaman 75-83.

Widodo, Suryo. 2013. Variabel-variabel Tersembunyi dalam Guru Matematika Kreatif. Prosiding Seminar Nasional Matematika dan Pendidikan Matematika dengan tema ” Penguatan Peran Matematika dan Pendi- 


\section{Prosiding: Evaluasi Kurikulum 2013 Mata Pelajaran Pendidikan Agama Islam Pada SMA di Jawa Tengah Dan D.I.Yogyakarta}

dikan Matematika untuk Indonesia yang Lebih Baik" pada tanggal 9 November 2013 di Jurusan Pendidikan Matematika FMIPA UNY.

Widoyoko, E. Putro. 2012. Evaluasi Program Pembelajaran.Panduan Praktis Bagi Pendidik dan Calon Pendidik. Yogyakarta: Pustaka Pelajar.

\section{Peraturan Perundangan}

Peraturan Menteri Pendidikan dan Kebudayaan Nomor 54 tahun 2013 tentang Standar Kompetensi Lulusan.

Peraturan Menteri Pendidikan dan Kebudayaan Nomor 59 Tahun 2014 tentang Kurikulum 2013 SMA/MA.

Peraturan Menteri Pendidikan dan Kebudayaan Nomor 64 Tahun 2013 tentang Standar Isi Pendidikan Dasar dan Menengah.

Peraturan Menteri Pendidikan dan Kebudayaan Nomor 65 Tahun 2013 tentang Standar Proses Pendidikan Dasar dan Menengah.

Peraturan Menteri Pendidikan dan Kebudayaan Nomor 66 Tahun 2013 tentang Standar Penilaian Pendidikan.

Peraturan Menteri Pendidikan dan Kebudayaan Nomor 69 Tahun 2013 tentang Kerangka Dasar dan Struktur Kurikulum SMA/MA.

\section{Sumber Rujuan dari Internet}

“Ini Keputusan Hasil Evaluasi Kurikulum 2013”. Diakses tanggal 24 Desember 2014 dari http://nasional.republika.co.id/berita/nasional/umum/ 14/12/06/ng4k0a-ini-keputusan-hasil-evaluasi-kurikulum-2013. 